\title{
Biological and Cytoprotective Effect of Piper kadsura Ohwi against Hydrogen-Peroxide-Induced Oxidative Stress in Human SW1353 Cells
}

\author{
Te-Yang Huang ${ }^{1}$, Chih-Chuan $\mathrm{Wu}^{2}$ and Wen-Ta Su ${ }^{2, * \mathbb{D}}$ \\ 1 Department of Orthopedic Surgery, Mackay Memorial Hospital, Taipei 104217, Taiwan; haungt33@gmail.com \\ 2 Department of Chemical Engineering and Biotechnology, National Taipei University of Technology, \\ Taipei 104217, Taiwan; cf1811@ntut.edu.tw \\ * Correspondence: f10549@mail.ntut.edu.tw; Tel.: +886-2-27712171 (ext. 2554); Fax: +886-2-27317117
}

\section{check for}

updates

Citation: Huang, T.-Y.; Wu, C.-C.; $\mathrm{Su}, \mathrm{W}$.-T. Biological and Cytoprotective Effect of Piper kadsura Ohwi against Hydrogen-Peroxide-Induced Oxidative Stress in Human SW1353 Cells. Molecules 2021, 26, 6287. https://doi.org/10.3390/ molecules26206287

\section{Academic Editors:}

Hosam O. Elansary, Agnieszka Szopa and Luciana Mosca

Received: 12 August 2021

Accepted: 22 September 2021

Published: 18 October 2021

Publisher's Note: MDPI stays neutral with regard to jurisdictional claims in published maps and institutional affiliations.

Copyright: (c) 2021 by the authors. Licensee MDPI, Basel, Switzerland. This article is an open access article distributed under the terms and conditions of the Creative Commons Attribution (CC BY) license (https:// creativecommons.org/licenses/by/ $4.0 /)$.

\begin{abstract}
Oxidative stress plays a role in regulating a variety of physiological functions in living organisms and in the pathogenesis of articular cartilage diseases. Piper kadsura Ohwi is a traditional Chinese medicine that is used as a treatment for rheumatic pain, and the extracts have anti-inflammatory and antioxidant effects. However, there is still no study related to cell protection by P. kadsura. The P. kadsura extracts (PKE) were obtained by microwave-assisted extraction, liquid-liquid extraction, and column chromatography separation. The extracts could effectively scavenge free radicals in the antioxidant test, the $\mathrm{EC}_{50}$ of extracts is approximately the same as vitamin C. PKE decreased the apoptosis of SW1353 cells treated with $\mathrm{H}_{2} \mathrm{O}_{2}$ and could upregulate the gene expression of antioxidant enzymes (SOD-2, GPx, and CAT) and the Bcl-2/Bax ratio, as well as regulate PARP, thus conferring resistance to $\mathrm{H}_{2} \mathrm{O}_{2}$ attack. PKE protects cells against apoptosis caused by free radicals through the three pathways of JNK, MEK/ERK, and p38 by treatment with MAPK inhibitor. The identified components of PKE were bicyclo [2.2.1] heptan-2-ol-1,7,7-trimethyl-,(1S-endo)-, alpha-humulene, and hydroxychavicol by gas chromatography-mass spectrometry.
\end{abstract}

Keywords: Piper kadsura Ohwi; microwave-assisted extraction; oxidative stress; SW1353; MAPKs pathways

\section{Introduction}

Osteoarthritis $(\mathrm{OA})$ is a progressive degenerative joint disease that affects cartilage, synovium, synovial joints, and muscles around the joints [1,2]. OA is most affected by age, obesity, local inflammation, and mechanical stresses. The main pathological changes of osteoarthritis occur in articular cartilage, which also affects subchondral bone, tendon, joint periosteum, and surrounding muscle. After degenerative changes in cartilage, the appearance of the cartilage surface is irregular, with cracks, ulcers, cartilage thickness reduction, and joints. Inflammation of the synovial membrane results in asymmetrical stenosis of the joint cavity, joint pain, stiffness, and dysfunction. Clinically, it is caused by extracellular matrix (ECM) degradation and dysregulation of some inflammatory factors [3]. Unbalanced reactive oxygen species (ROS) may also destroy the structure of chondrocytes, enhance cell death signals, and reduce cell integrity, leading to cartilage damage. The dysregulation of ECM anabolism, abnormal generation of ROS, as well as overproduction of proteolytic enzymes and inflammatory cytokines can accelerate the degradation process of cartilage [4]. ROS are the byproducts of normal cellular metabolism and are thought to be essential for regulating physiological functions involved in the development and modulation of the immune system through activation of various cellular signaling pathways. A dramatic increase in ROS is called oxidative stress, which is an imbalance between the ratio of free radicals to antioxidants, which interferes with the normal redox state of the cell and damages the cell's proteins, lipids, and DNA [5].

$\mathrm{H}_{2} \mathrm{O}_{2}$ is the major source of endogenous ROS; it has been extensively used to induce oxidative stress in in vitro models and to induce apoptosis in several types of cells, in- 
cluding chondrocyte and neuronal cells [6]. When ROS exceeds the ability of cells to load, the internal antioxidant capacity and oxidative capacity of the cells are unbalanced. This is called oxidative stress, and this result can destroy the normal structure of the mitochondria in the cell and its function, leading to death or apoptosis $[7,8]$.

Studies on primary human chondrocytes are limited by the lack of a sufficient number from the donors. In addition, the isolated cells, primary human chondrocytes, very easily lose their biological and functional characterization in vitro culture and differ considerably with donors [9]. The human chondrosarcoma-derived cell line SW1353 is a promising substitute for a chondrocytic experimental model, displaying sufficient proliferative activity and presenting a consistent response to the phenotype of primary human chondrocytes [10]. It is often used as a model for osteoarthritis studies [11].

Piper kadsura (Choisy) Ohwi (Acta Phytotax. Geobot. 3(2):81 (1934)) is a perennial vine herb that grows in the forests of Taiwan and is widely used for the treatment of asthma and arthritic conditions [12]. Previous studies have shown that extracts of P. kadsura have anti-neuritis [13], anti-platelet activating factor [14], anti-inflammation [15], and antioxidation [16] effects, as well as other effects.

Microwave-assisted extraction (MAE) has achieved remarkable results in the areas of chemical synthesis, biomedicine, and new-material manufacturing. This technique can convert electromagnetic energy into heat at a specific frequency and temperature to rapidly heat the reaction materials. MAE can achieve high yields, selectivity, and reaction rates, and this method can use less solvent, consume less energy, and produce less waste than do traditional heating syntheses [17].

SW1353 cells showing oxidative stress induced by $\mathrm{H}_{2} \mathrm{O}_{2}$ possess properties similar to those of the articular chondrocytes of OA [6]. The aim of this study is to investigate the protective effects of P. kadsura extract (PKE) for oxidative stress to cells on OA-related symptoms and cellular apoptosis.

\section{Results}

2.1. The Optimal Extraction Parameters for P. kadsura by MAE

On the basis of $4 \mathrm{~g}$ of ground sample, the parameters in the MAE system were changed to obtain the best extraction results. Figure 1 indicates that the maximal yields of extraction were at $800 \mathrm{~W}$ power, 30 min extraction time, $42{ }^{\circ} \mathrm{C}$ operative temperature, and $1: 15 \mathrm{solid} /$ ethanol $(\mathrm{g} / \mathrm{mL})$ ratio, with the extracted yield being $11.9 \pm 0.76 \%$.

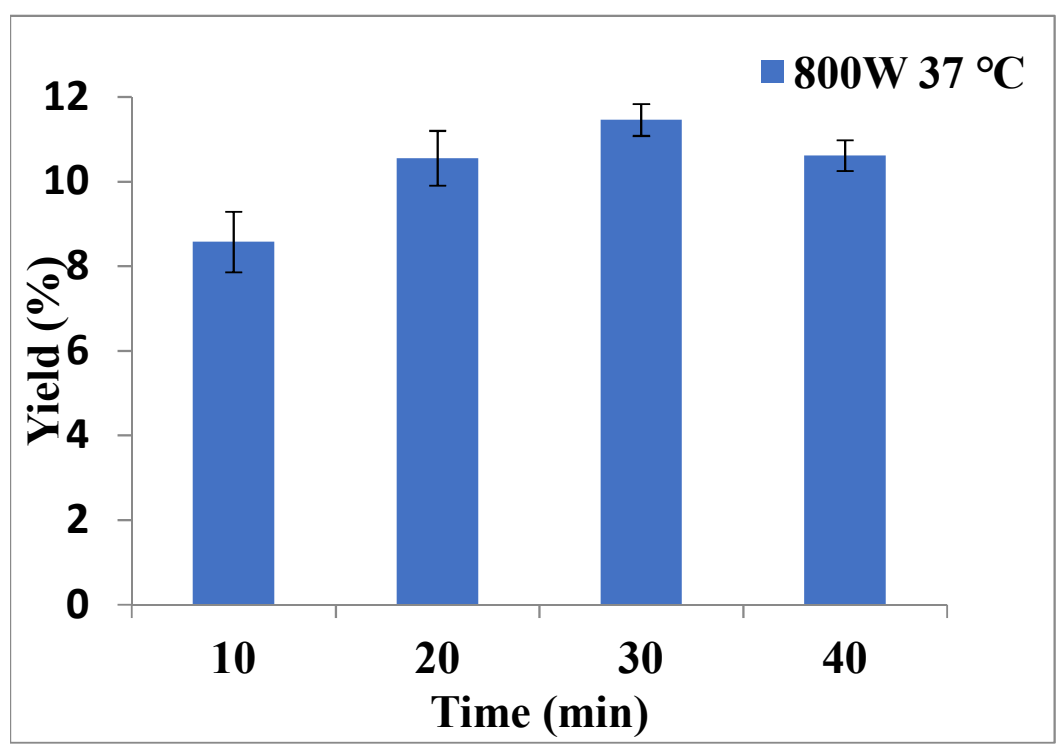

Figure 1. Cont. 

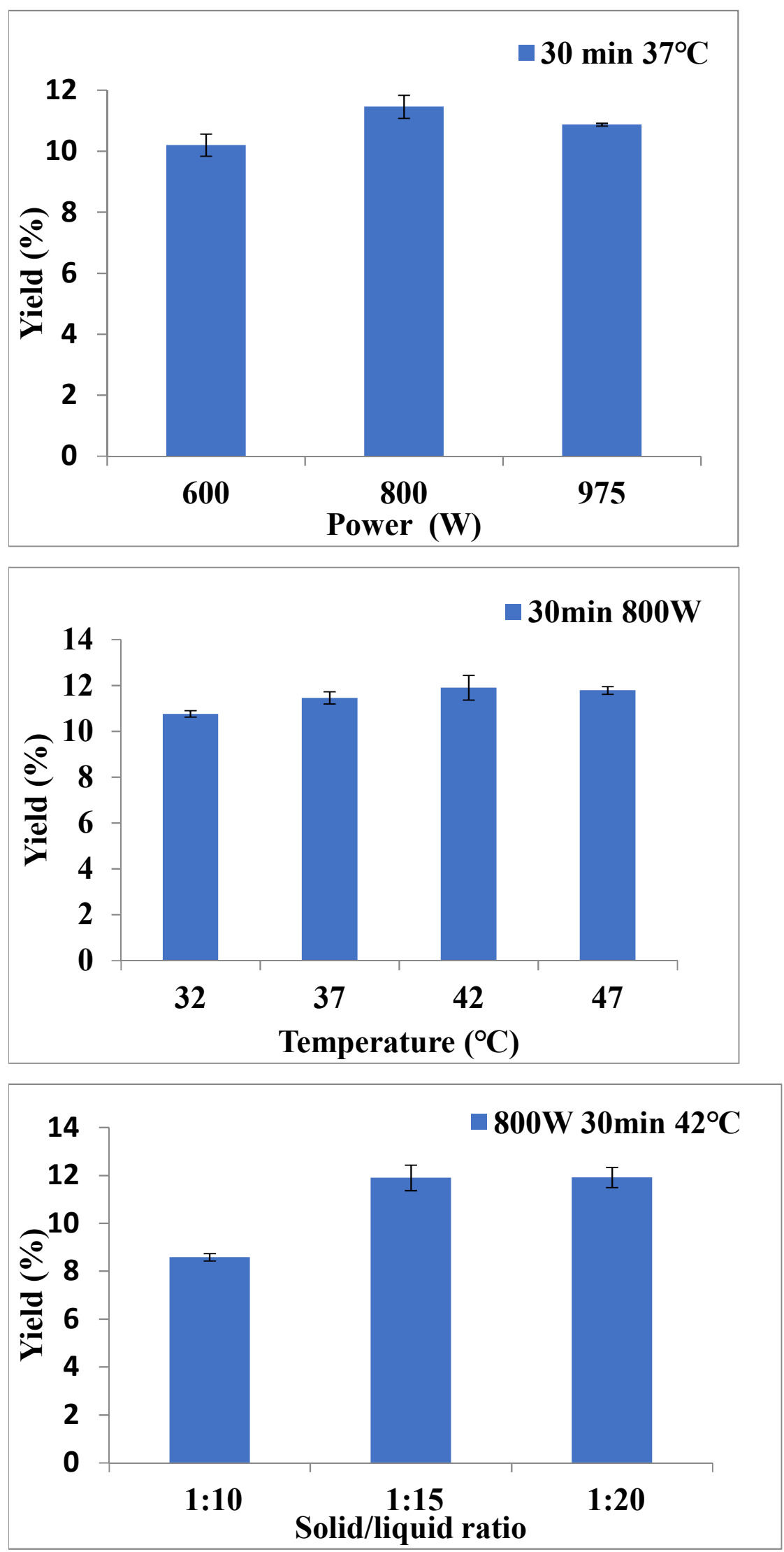

Figure 1. The yields of various parameters in the MAE; the maximal yield of extracts were at $800 \mathrm{~W}$ power, 30 min extract time, $42^{\circ} \mathrm{C}$ operative temperature, and 1:15 solid/ethanol $(\mathrm{g} / \mathrm{mL})$ ratio. 


\subsection{Purification of Crude Extract and Biological Characteristics}

The crude extract of $P$. kadsura from MAE was continuously separated by liquid-liquid extraction between the polarity differences of various solvents. The order of extraction yields of different organic solvents is ethyl ether fraction $>$ aqueous fraction $>$ hexane fraction $>$ ethyl acetate fraction, as shown in Table 1 . Thus, most of the extracts dissolved into the ethyl ether fraction indicated that the extracts are low- to medium-polarity compounds.

Table 1. The yield of different liquid-liquid separation.

\begin{tabular}{cc}
\hline Extract & Yield (\%) \\
\hline Crude fraction & $11.90 \pm 0.54$ \\
n-Hexane fraction & $1.69 \pm 0.36$ \\
Ethyl ether fraction & $4.40 \pm 0.20$ \\
Ethyl acetate fraction & $0.44 \pm 0.06$ \\
Aqueous fraction & $2.73 \pm 0.15$ \\
\hline
\end{tabular}

Based on the calibration curve $\left(y=0.0087 x+0.1033, R^{2}=0.997\right)$ of gallic acid (50-250 mg/L), the content of phenolic in crude and various solvent extracts ranged from $1256.6 \pm 0.7$ to $29.6 \pm 0.4 \mathrm{mg}$ gallic acid/g dried extract, as seen in Figure 2a. Ethyl ether extract had the greatest phenolic content, while the smallest phenolic content was found in aqueous extract. Similarly, the calibration curve $\left(y=0.0072 x+0.0234, R^{2}=0.9966\right)$ of quercetin $(50-250 \mathrm{mg} / \mathrm{L})$ was employed for evaluation of the flavonoid content of crude and various solvent extracts. The maximum amount of flavonoid was found in the ethyl ether extract $(10.44 \pm 0.09 \mathrm{mg}$ quercetin/g dried extract), while the lowest amount (1.12 $\pm 0.1 \mathrm{mg}$ quercetin/g dried extract) was found in the aqueous extract, as shown in Figure 2b. Table 2 shows that the crude and various solvent extracts of $P$. kadsura have an obvious inhibition zone effect on most strains. Except for P. aeruginosa ATCC 27853 and ATCC 29260, the average inhibition zone diameter is more than $20.0 \mathrm{~mm}$. Extracted by liquid-liquid distribution, the ethyl ether extract has a significant antimicrobial effect on S. aureus ATCC 6538P, A. baumannii ATCC 19606, and E. coli ATCC 25257 strains, while the aqueous and ethyl acetate extracts have no significant antimicrobial ability.

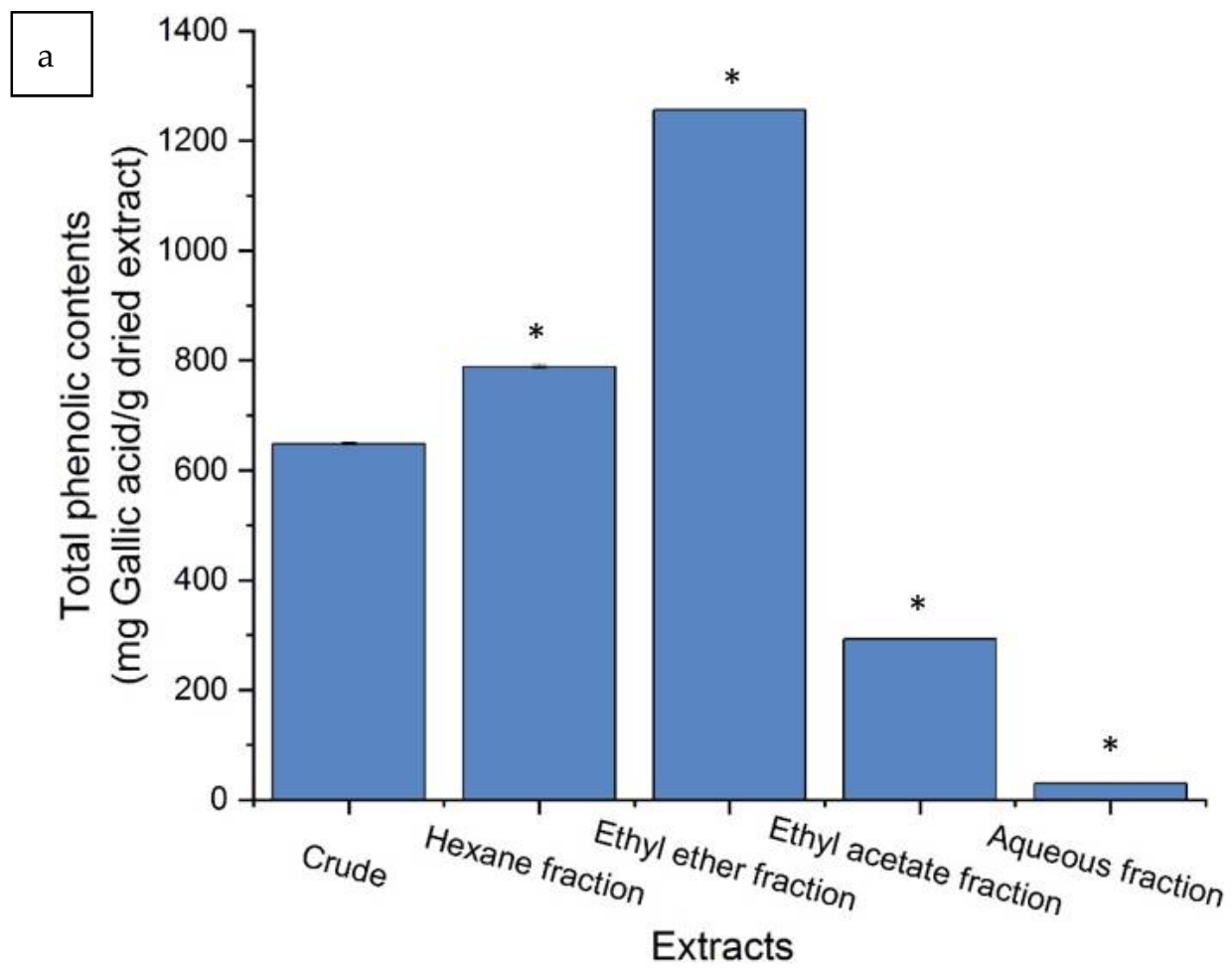

Figure 2. Cont. 


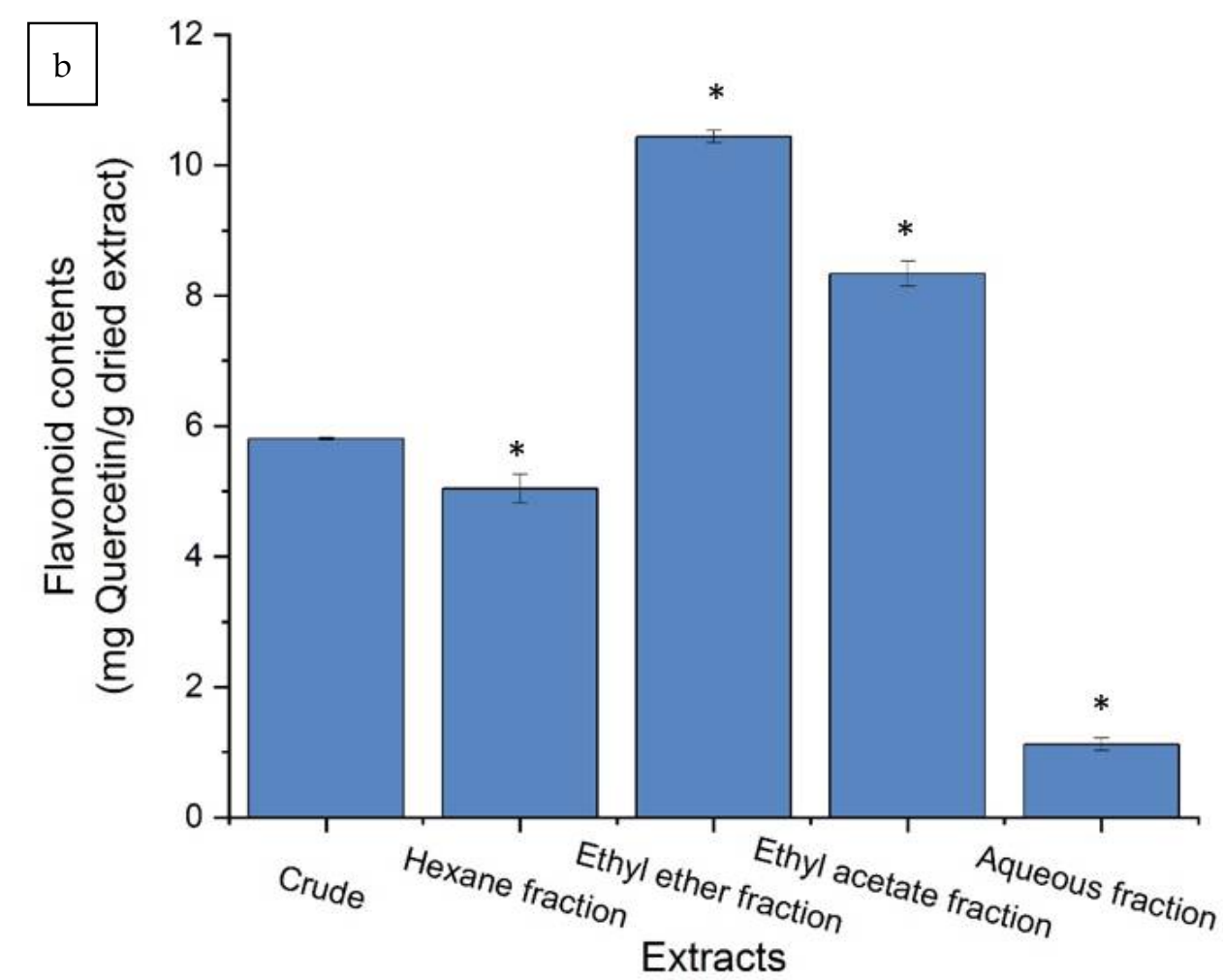

Figure 2. The total phenolic acids (a) and flavonoid contents (b) in crude and various solvent extracts of $P$. kadsura. Values are expressed as mean $\pm \mathrm{SD}(n=3),{ }^{*} p<0.05$ for compared with crude group.

Table 2. Antimicrobial activity of crude and various liquid-liquid extracts of P. kadsura.

\begin{tabular}{|c|c|c|c|c|c|c|}
\hline \multirow[b]{2}{*}{ Strains } & \multicolumn{6}{|c|}{ DIZ (mm) } \\
\hline & $\begin{array}{c}\text { Crude } \\
1000.0 \\
(\mathrm{mg} / \mathrm{mL})\end{array}$ & $\begin{array}{c}\text { Hexane } \\
100.0 \\
(\mathrm{mg} / \mathrm{mL})\end{array}$ & $\begin{array}{c}\text { Diethyl Ether } \\
100.0 \\
(\mathrm{mg} / \mathrm{mL})\end{array}$ & $\begin{array}{c}\text { Ethyl Acetate } \\
100.0 \\
(\mathrm{mg} / \mathrm{mL})\end{array}$ & $\begin{array}{c}\text { Aqueous } \\
100.0 \\
(\mathrm{mg} / \mathrm{mL})\end{array}$ & $\begin{array}{c}\text { Tetracycline } \\
7.50 \\
(\mathrm{mg} / \mathrm{mL})\end{array}$ \\
\hline P. aeruginosa ATCC 27853 & $22.60 \pm 0.90$ & $14.28 \pm 1.73$ & $16.05 \pm 3.45$ & $10.75 \pm 0.55$ & $6.25 \pm 0.25$ & $15.50 \pm 0.20$ \\
\hline P. aeruginosa ATCC 29260 & $14.20 \pm 0.20$ & $9.20 \pm 1.20$ & $14.23 \pm 0.23$ & $7.23 \pm 0.23$ & - & $14.20 \pm 0.20$ \\
\hline S. aureus ATCC 6538P & $25.73 \pm 1.73$ & $20.75 \pm 0.75$ & $20.75 \pm 1.25$ & $12.50 \pm 0.50$ & $7.45 \pm 0.03$ & $31.93 \pm 2.43$ \\
\hline A. baumannii ATCC 19606 & $23.50 \pm 1.50$ & $21.03 \pm 1.33$ & $26.20 \pm 0.28$ & $8.48 \pm 0.05$ & - & $18.00 \pm 0.00$ \\
\hline E.coli ATCC 25257 & $21.70 \pm 0.50$ & $19.50 \pm 2.00$ & $22.15 \pm 0.15$ & $7.38 \pm 0.05$ & - & $26.08 \pm 0.53$ \\
\hline
\end{tabular}

Data $=$ mean \pm SD; -:no active.

The concentration for SW1535 cells viability treated via various liquid-liquid extracts and $\mathrm{H}_{2} \mathrm{O}_{2}$ was confirmed beforehand (data not shown), and then various liquid-liquid extracts and $\mathrm{H}_{2} \mathrm{O}_{2}$ co-treatments were used to measure the cell viability. Figure $3 \mathrm{a}$ indicates that the ethyl ether extract and ethyl acetate extract resulted in higher survival rate and better cytoprotective ability than other extracts. Figure $3 \mathrm{~b}$ shows the scavenging ability versus the different concentrations of various liquid-liquid extracts upon doing a DPPH assay. The ethyl ether extract showed the best antioxidant ability, and its $\mathrm{EC}_{50}$ (concentration for $50 \%$ of maximal effect) was of $7.19 \pm 0.8 \mu \mathrm{g} / \mathrm{mL}$, only slightly inferior to that of vitamin $\mathrm{C}\left(\mathrm{EC}_{50}=4.60 \pm 0.66 \mu \mathrm{g} / \mathrm{mL}\right)$. The lower the $\mathrm{EC}_{50}$, the stronger the ability to capture free radicals. Therefore, the ethyl ether fraction was further purified through column chromatography based on extract yield, total polyphenols and flavonoid contents, antimicrobial activity, cell viability, and antioxidant capacity. 

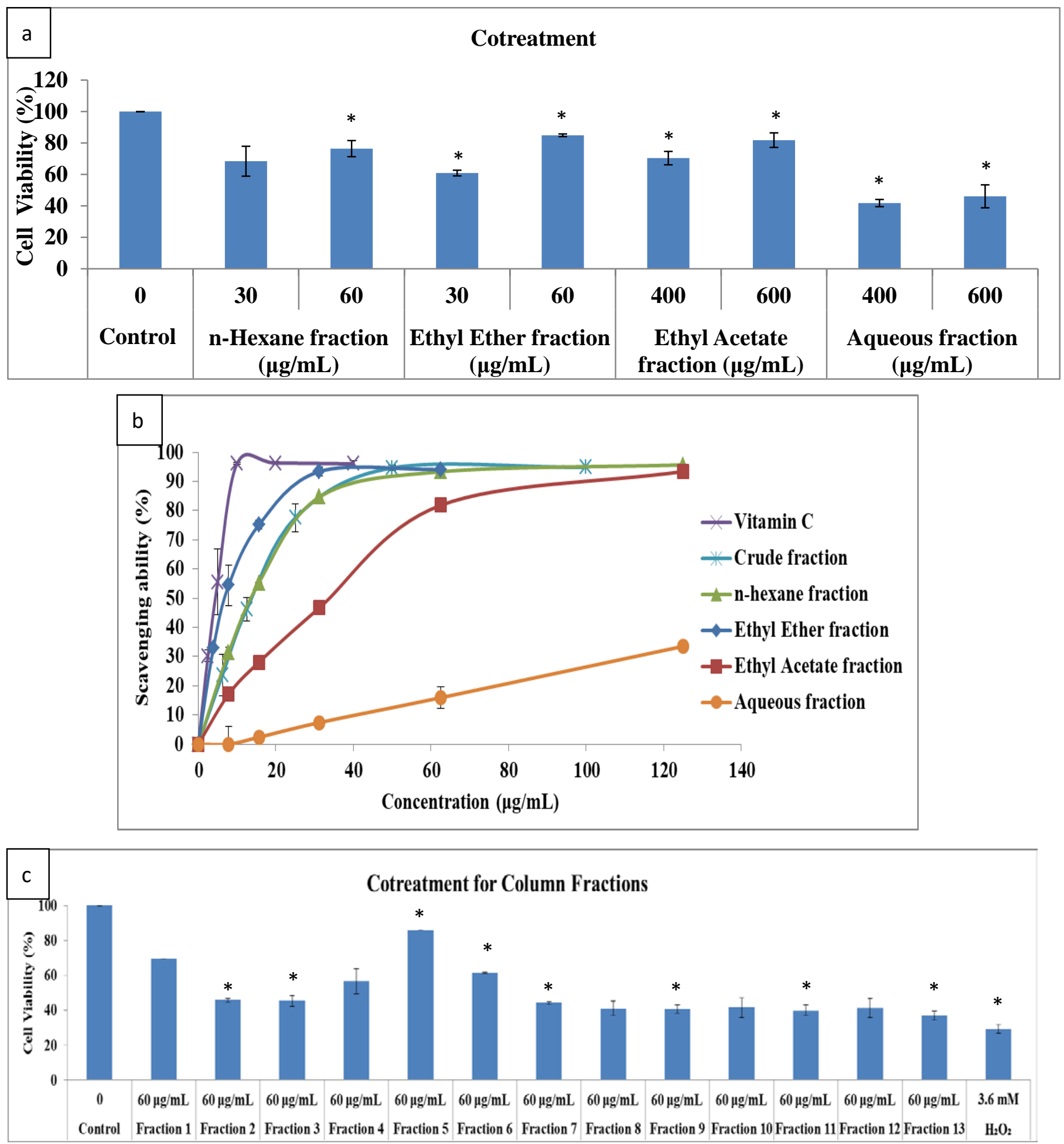

Figure 3. Cont. 

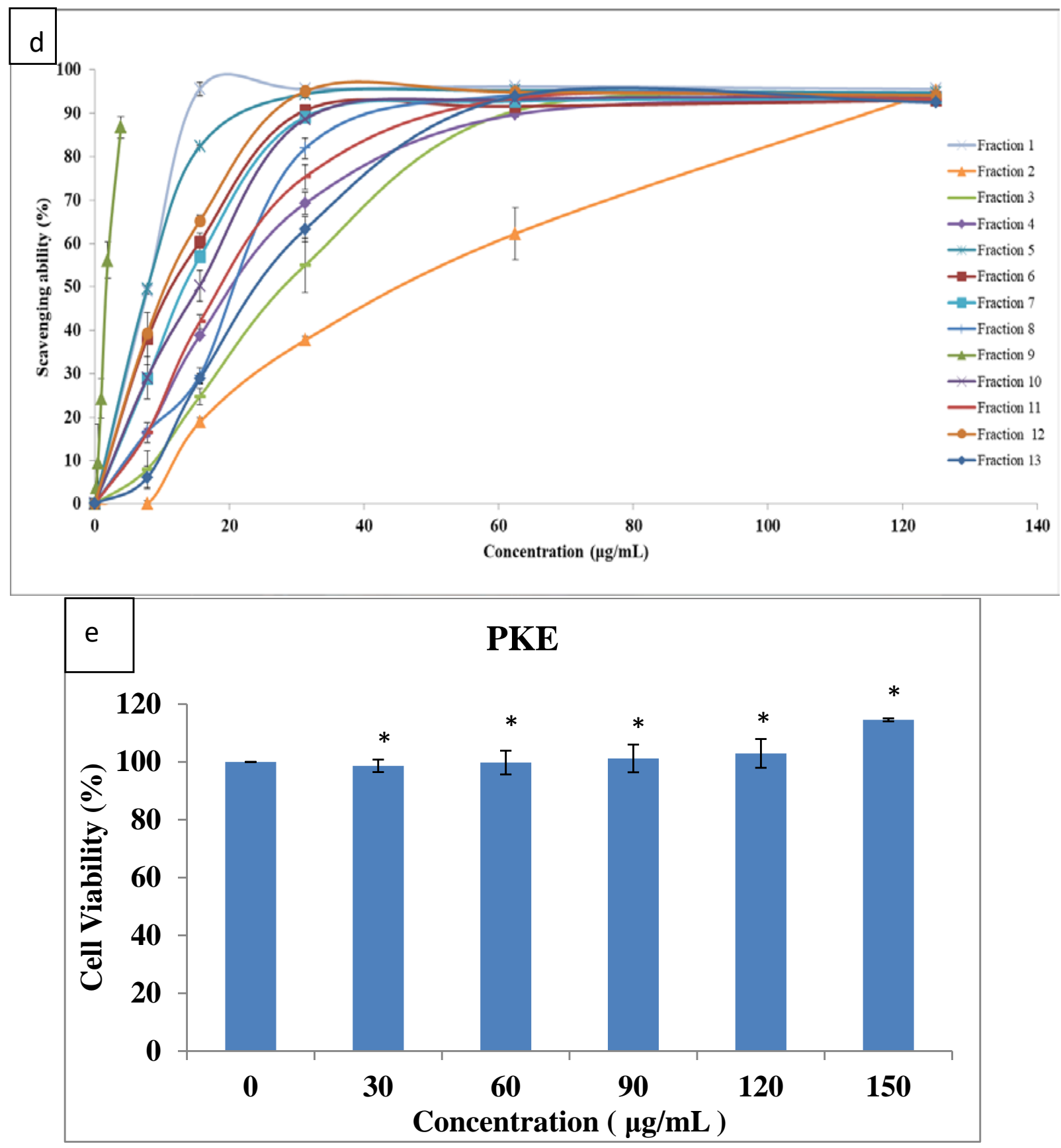

Figure 3. The cell viability for various liquid-liquid extracts and $\mathrm{H}_{2} \mathrm{O}_{2}$ co-treatment with different concentrations (a), the DPPH assay treated with various liquid-liquid extracts (b), cell viability for various fraction extracts and $\mathrm{H}_{2} \mathrm{O}_{2}$ co-treatment (c), the DPPH assay treated with extracts of various fractions $(\mathbf{d})$, and the dose-dependent cell viability of the PKE (e). Values are expressed as mean \pm SD $(n=3),{ }^{*} p<0.05$ for compared with control group or 0 concentration.

To choose the 6:1 hexane/ethyl acetate ratio to pure methanol as eluent liquid based on thin-layer chromatography, we separated 13 fractions from open-column chromatography. The fraction yield from open-column chromatography is shown in Table 3. The fractions with $\mathrm{H}_{2} \mathrm{O}_{2}$ were used to co-treat SW1353 cells for the cell viability assay. Figure 3c shows that the best cell survival was with Fraction 5. The DPPH assay of various column fractions is shown in Figure 3d, in which the best antioxidant ability was from Fraction 9 $\left(\mathrm{EC}_{50}=1.77 \pm 0.08 \mu \mathrm{g} / \mathrm{mL}\right)$, followed by Fraction $5\left(\mathrm{EC}_{50}=7.9 \pm 0.14 \mu \mathrm{g} / \mathrm{mL}\right)$ and Fraction $1\left(\mathrm{EC}_{50}=7.96 \pm 0.09 \mu \mathrm{g} / \mathrm{mL}\right)$. On the basis of various fraction yields, cell viability, and antioxidant capacity, Fraction 5 (as PKE) was used as the test drug in subsequent ex- 
periments. The cell viability of the PKE is dose-dependent, as shown in Figure 3e. Based on the result, the PKE is not toxic for SW1353 cells.

Table 3. The yield of various fraction of column separation.

\begin{tabular}{ccc}
\hline Extract & Elution & Yield (\%) \\
\hline Fraction 1 & Hex:EA $=6: 1$ & $1.73 \pm 0.31$ \\
Fraction 2 & Hex:EA $=6: 1$ & $0.21 \pm 0.01$ \\
Fraction 3 & Hex:EA $=3: 1$ & $0.06 \pm 0.00$ \\
Fraction 4 & Hex:EA $=3: 1$ & $0.17 \pm 0.01$ \\
Fraction 5 & Hex:EA $=1: 1$ & $0.33 \pm 0.03$ \\
Fraction 6 & Hex:EA $=1: 1$ & $0.52 \pm 0.09$ \\
Fraction 7 & Hex:EA $=1: 1$ & $0.11 \pm 0.01$ \\
Fraction 8 & Hex:EA $=1: 1$ & $0.21 \pm 0.01$ \\
Fraction 9 & EA $=1$ & $0.34 \pm 0.03$ \\
Fraction 10 & EA $=1$ & $0.21 \pm 0.01$ \\
Fraction 11 & EA $=1$ & $0.15 \pm 0.00$ \\
Fraction 12 & EA $=1$ & $0.09 \pm 0.00$ \\
Fraction 13 & MeOH $=1$ & $0.64 \pm 0.08$ \\
\hline
\end{tabular}

n-Hexane: Hex, ethyl acetate: EA, methanol: $\mathrm{MeOH}$.

\subsection{Apoptosis Assay and Cell Morphology Change}

Cellular apoptosis in SW1353 cells treated with PKE $(60 \mu \mathrm{g} / \mathrm{mL})$, PKE $(60 \mu \mathrm{g} / \mathrm{mL})$ with $3.6 \mathrm{mM}$ added $\mathrm{H}_{2} \mathrm{O}_{2}$, and $3.6 \mathrm{mM} \mathrm{H}_{2} \mathrm{O}_{2}$ for $24 \mathrm{~h}$ was determined according to cellular vitality. Cellular morphology was observed in SW1353 cells treated with PKE or $\mathrm{H}_{2} \mathrm{O}_{2}$ for $24 \mathrm{~h}$, as shown in Figure 4a. The cells treated with PKE showed normal morphology, but the cells treated with $\mathrm{H}_{2} \mathrm{O}_{2}$ shrank significantly, and apoptotic bodies were observed. However, cell shrinkage or apoptotic bodies were not obvious for cells treated with PKE with added $\mathrm{H}_{2} \mathrm{O}_{2}$. Hence, PKE has significant ability to resist oxidative stress. The proportions of apoptotic SW1353 cells were 10.5\%, 18.0\%, and 28.4\% under treatment with PKE, PKE with added $\mathrm{H}_{2} \mathrm{O}_{2}$, and $\mathrm{H}_{2} \mathrm{O}_{2}$, respectively, and that for the control was $10.0 \%$, as seen in Figure $4 \mathrm{~b}$. This result indicates that $\mathrm{H}_{2} \mathrm{O}_{2}$ can cause cell apoptosis, but PKE protects cells from oxidative stress. The viability of L929 fibroblast cells treated with $60 \mu \mathrm{g} / \mathrm{mL}$ of PKE for $24 \mathrm{~h}$ and $48 \mathrm{~h}$ were $94.67 \%$ and $108.27 \%$, respectively. Thus, PKE is not toxic to normal non-cancerous cells. 

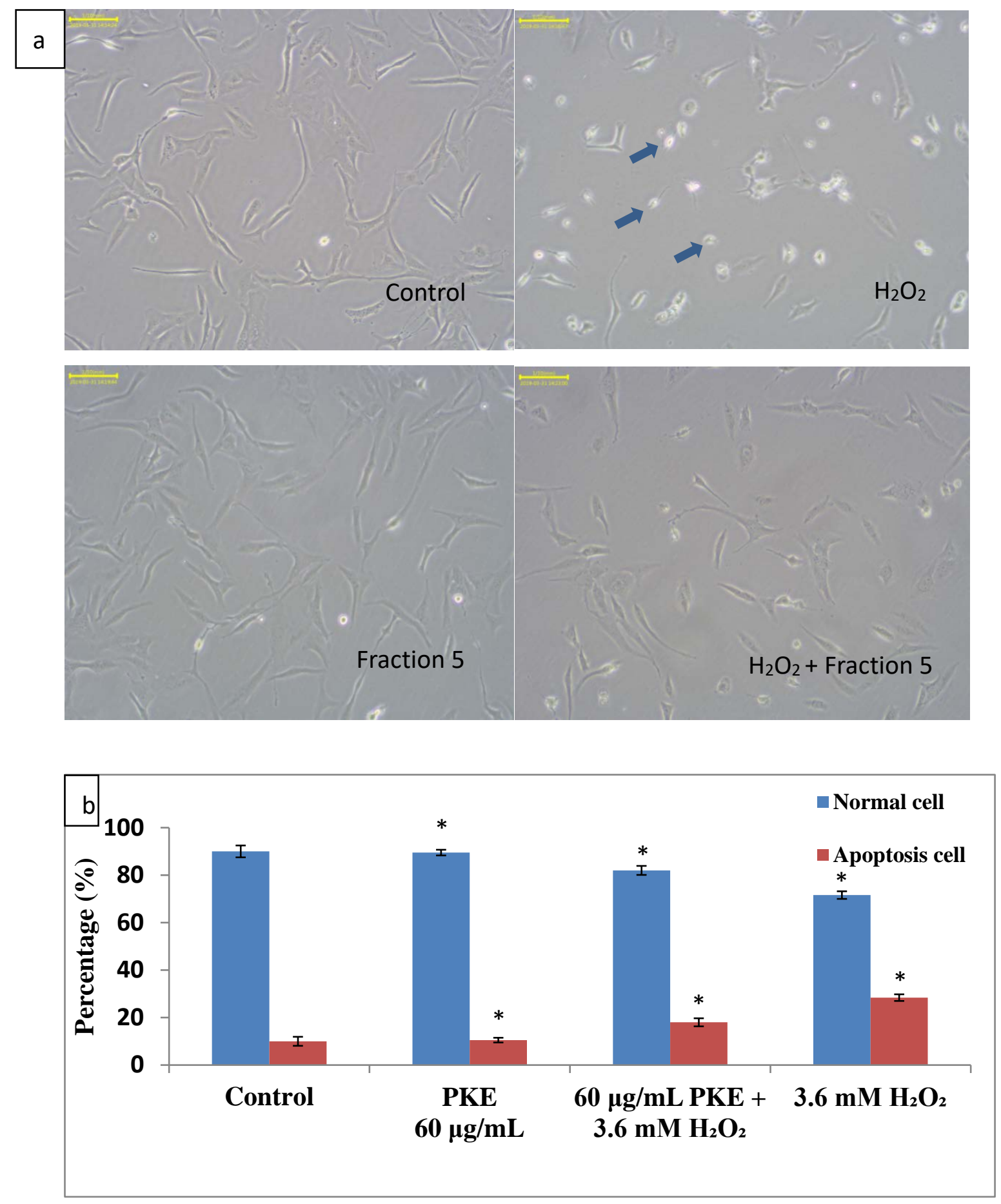

Figure 4. Cellular morphology of SW1353 treated with PKE or $\mathrm{H}_{2} \mathrm{O}_{2}$ for $24 \mathrm{~h}$ (the arrows are the apoptotic bodies) (a); the proportion of apoptotic SW1353 cells treated with PKE extract $(60 \mu \mathrm{g} / \mathrm{mL}), \mathrm{PKE}(60 \mu \mathrm{g} / \mathrm{mL})$ with $3.6 \mathrm{mM}$ added $\mathrm{H}_{2} \mathrm{O}_{2}$, and $3.6 \mathrm{mM} \mathrm{H}_{2} \mathrm{O}_{2}$ for $24 \mathrm{~h}(\mathbf{b})$. scale bar $=100 \mu \mathrm{m}$. Values are expressed as mean $\pm \mathrm{SD}(n=3),{ }^{*} p<0.05$ for compared with control group.

\subsection{ROS Assay}

SW1353 cells were treated with PKE $(60 \mu \mathrm{g} / \mathrm{mL})$, PKE $(60 \mu \mathrm{g} / \mathrm{mL})$ with $3.6 \mathrm{mM}$ added $\mathrm{H}_{2} \mathrm{O}_{2}$, and $3.6 \mathrm{mM} \mathrm{H}_{2} \mathrm{O}_{2}$ for $24 \mathrm{~h}$, and then cells were stained with CM-H2DCFDA to measure fluorescent expression. Table 4 indicates that the maximal expression of ROS $(73.73 \pm 1.54 \%)$ was in cells treated with $\mathrm{H}_{2} \mathrm{O}_{2}$, but PKE protects SW1353 cells from ROS and reduces ROS intensity to $70.94 \pm 0.92 \%$. 
Table 4. The ROS content of different treatments.

\begin{tabular}{cc}
\hline Treated Drug & ROS Content(\%) \\
\hline $60 \mu \mathrm{g} / \mathrm{mL}$ Fraction 5 & $67.44 \pm 1.08$ \\
\hline $60 \mu \mathrm{g} / \mathrm{mL}$ Fraction $5+3.6 \mathrm{mM} \mathrm{H}_{2} \mathrm{O}_{2}$ & $70.94 \pm 0.92$ \\
\hline $3.6 \mathrm{mM} \mathrm{H}_{2} \mathrm{O}_{2}$ & $73.73 \pm 1.54$ \\
\hline
\end{tabular}

\section{5. $q R T-P C R$}

The gene expression of the antioxidant enzyme SOD-2 can be upregulated by $\mathrm{H}_{2} \mathrm{O}_{2}$ and PKE simultaneously (Figure 5a). The upregulation expression of PKE is 1.2-fold higher than that of $\mathrm{H}_{2} \mathrm{O}_{2}$ only. Both the gene expression of GPx and CAT were downregulated by the $\mathrm{H}_{2} \mathrm{O}_{2}$ treatment, but the expression by PKE treatment was upregulated 1.26- and 3.69-fold in Figure 5b,c, respectively. The Bcl-2/Bax ratio was significantly upregulated by treatment with PKE and was downregulated slowly by treatment with $\mathrm{H}_{2} \mathrm{O}_{2}$; however, the expression of Bcl-2/Bax was still increased by PKE combined with $\mathrm{H}_{2} \mathrm{O}_{2}$ treatment simultaneously, as seen in Figure 5d. Figure 5e indicates that caspase- 3 expression was increased by the $\mathrm{H}_{2} \mathrm{O}_{2}$ treatment, but the expression was downregulated by PKE treatment. These results reveal that $\mathrm{H}_{2} \mathrm{O}_{2}$-treated SW1353 cells show induced programmed cellular death via the mitochondrial pathway, and that PKE can slow the apoptosis by regulating the antioxidant enzymes SOD-2, CAT, and GPx to protect cells.

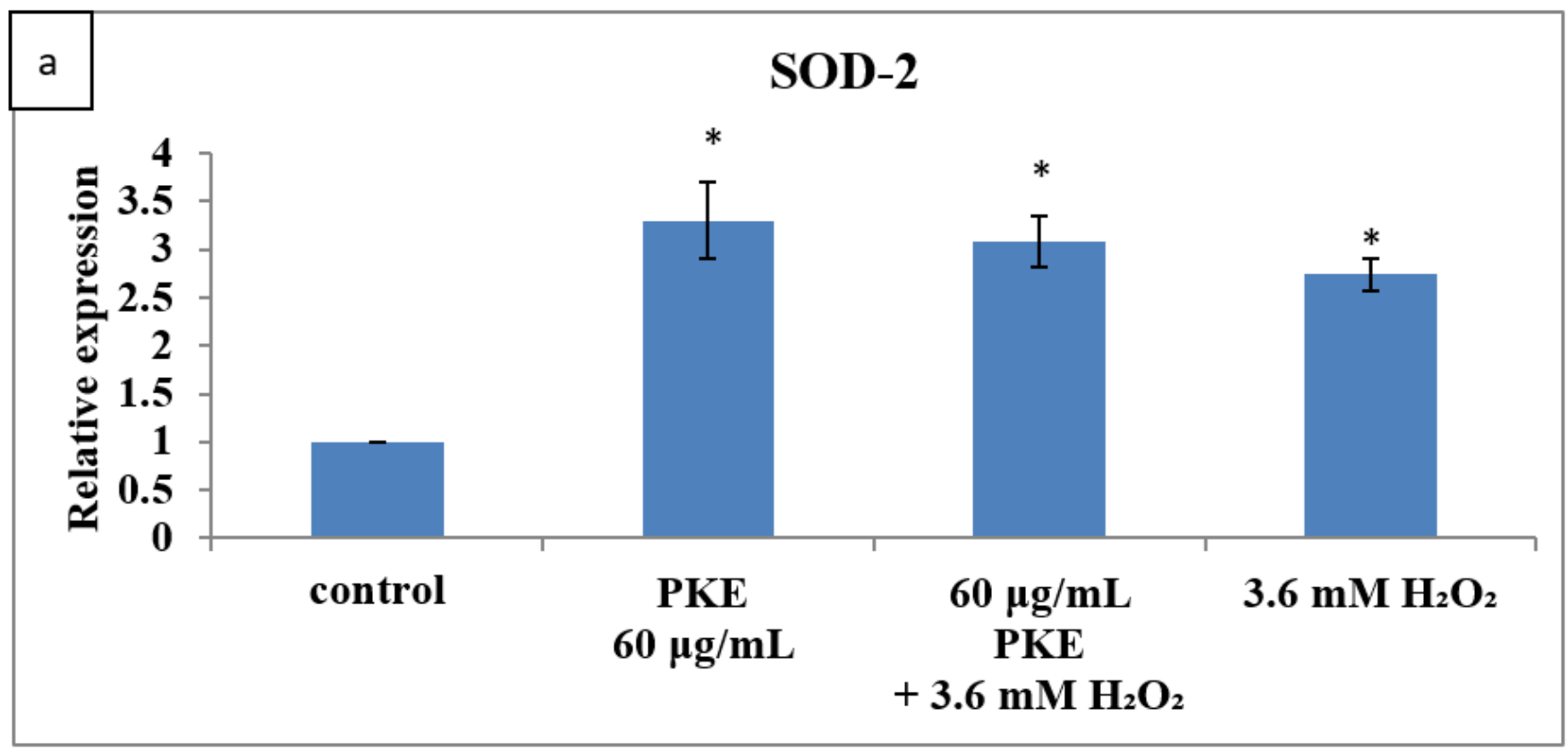

Figure 5. Cont. 

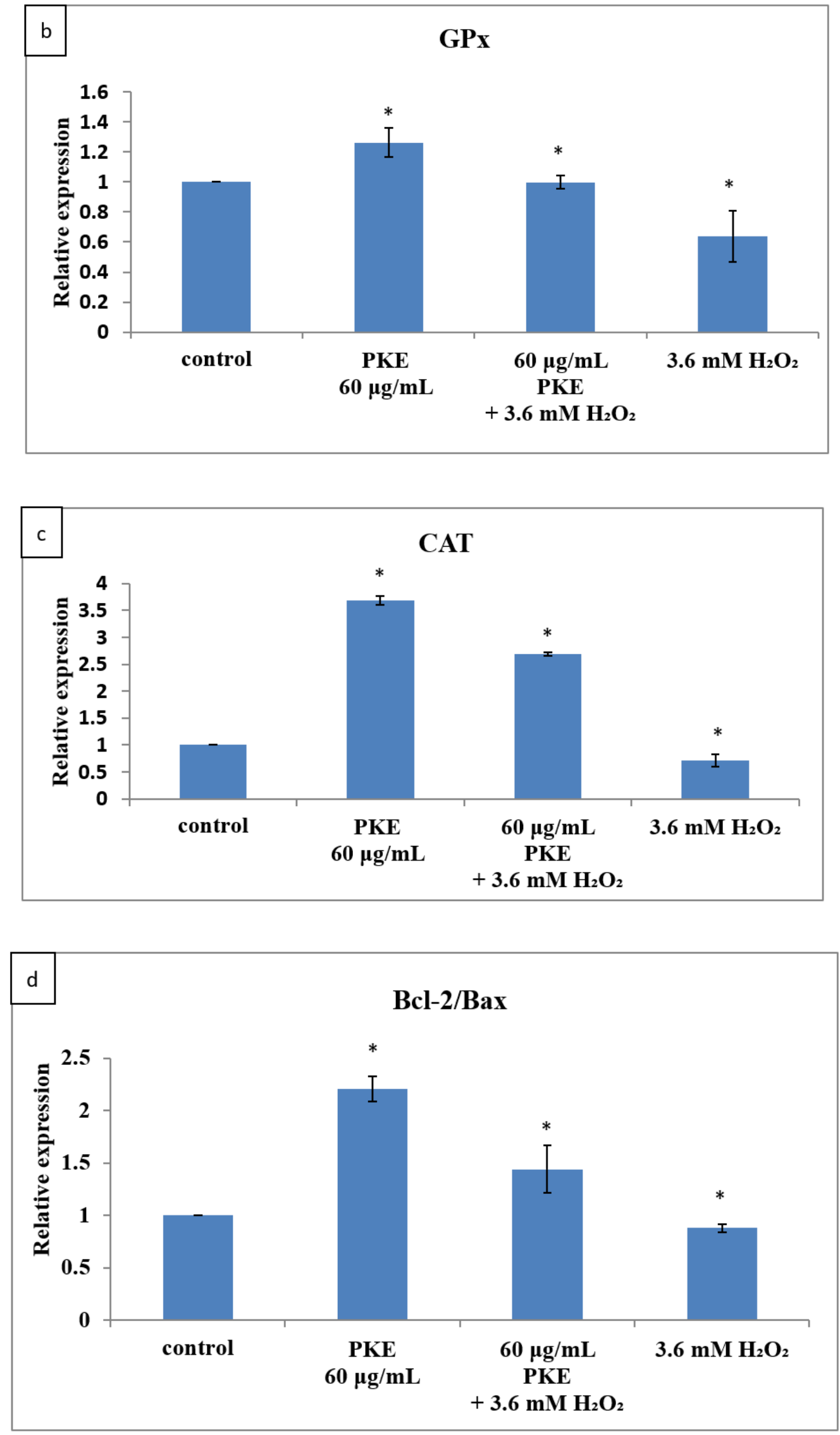

Figure 5. Cont. 


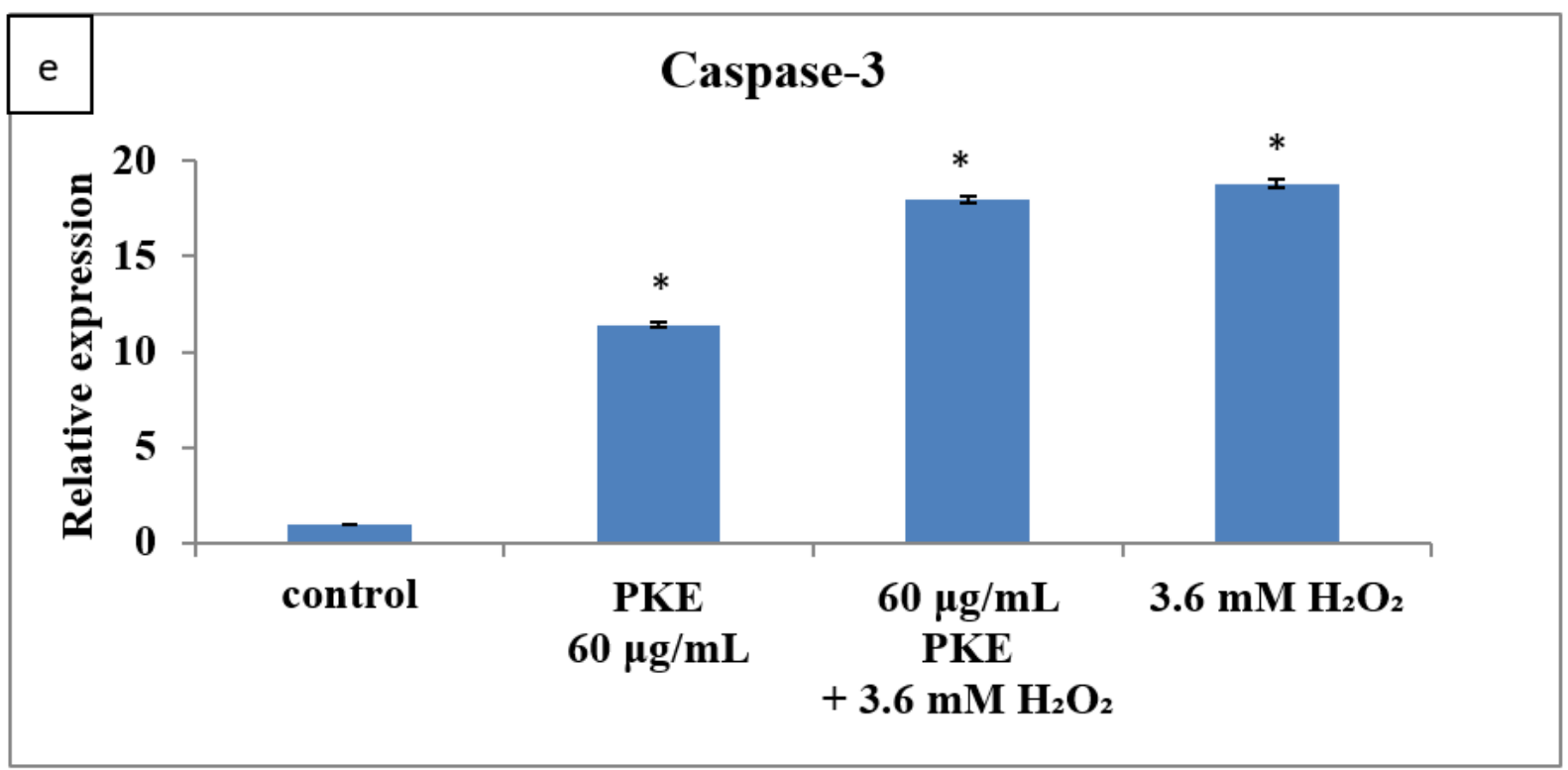

Figure 5. The gene expression of the antioxidant enzymes SOD-2 (a), GPx (b), and CAT (c), as well as the Bcl-2/Bax ratio (d), and caspase-3 (e) after cells were treated with PKE extract $(60 \mu \mathrm{g} / \mathrm{mL})$, PKE $(60 \mu \mathrm{g} / \mathrm{mL})$ with $3.6 \mathrm{mM}$ added $\mathrm{H}_{2} \mathrm{O}_{2}$, and $3.6 \mathrm{mM} \mathrm{H}_{2} \mathrm{O}_{2}$ for $24 \mathrm{~h}$. Values are expressed as mean $\pm \mathrm{SD}(n=3),{ }^{*} p<0.05$ for compared with control group.

Since $\mathrm{H}_{2} \mathrm{O}_{2}$ is regulated by the MAPK family, inhibitors were added to clarify pathways that protect cells by PKE treatment. Figure 6 indicates that Bax expression was downregulated significantly by addition with the inhibitors, such as SB 203580-p38 MAPK, U0126-MKK, and SP600125-JNK, and the expressions of Bcl-2 and SOD-2 were upregulated.

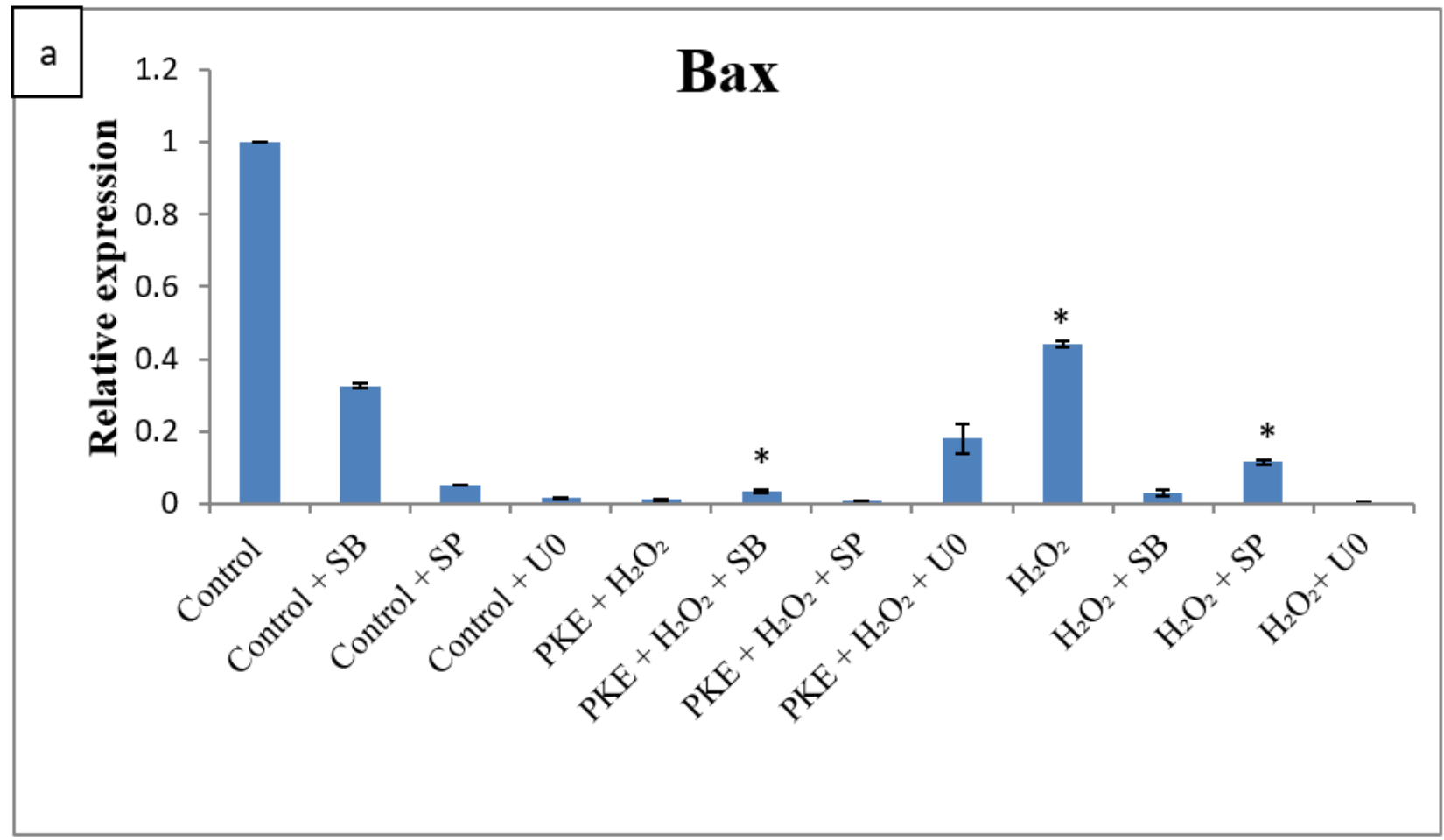

Figure 6. Cont. 

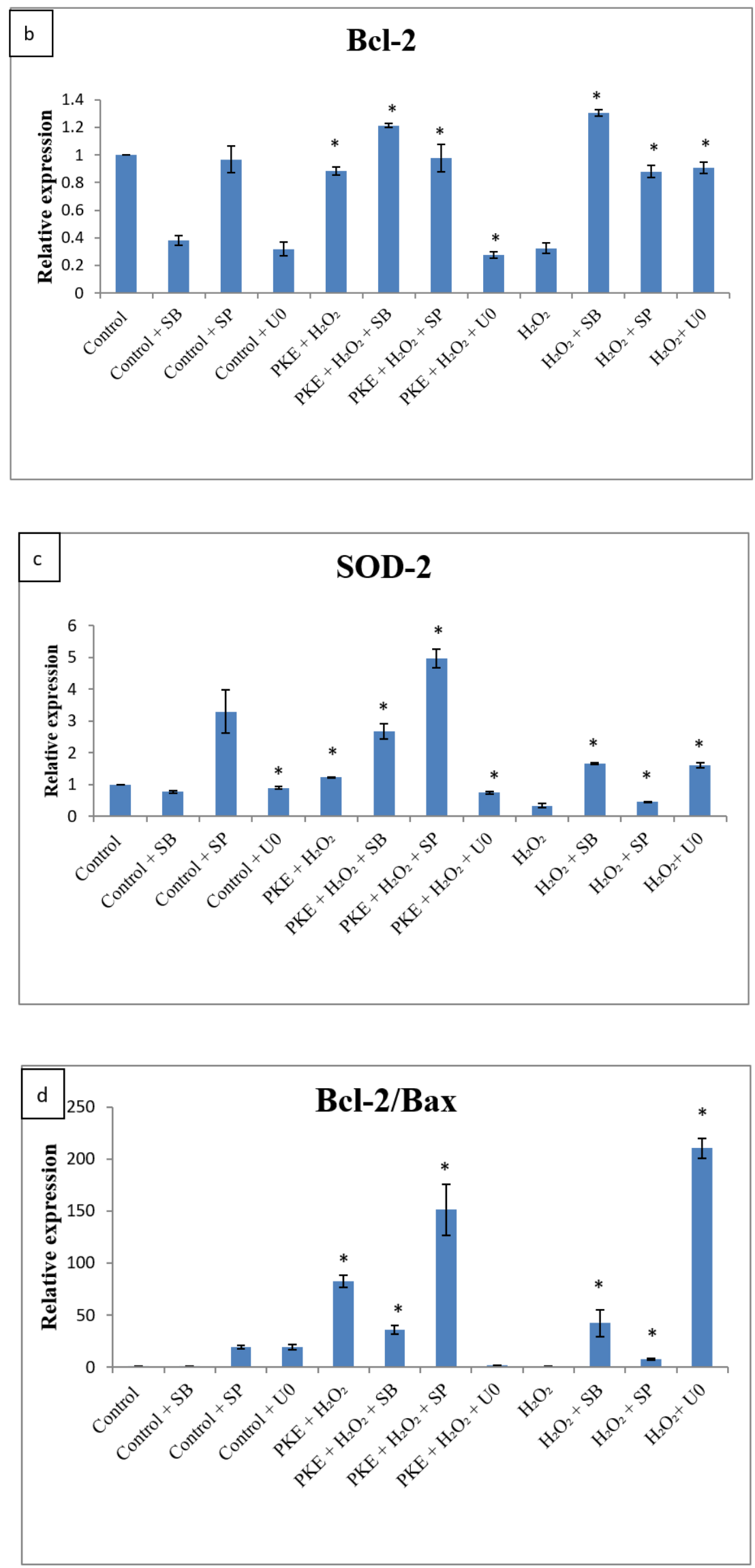

Figure 6. The gene expression of Bax (a), Bcl-2 (b), SOD-2 (c), and Bcl-2/Bax (d) after SW1353 was treated with MAPK inhibitors with added PKE or $\mathrm{H}_{2} \mathrm{O}_{2}$. Values are expressed as mean $\pm \mathrm{SD}(n=3)$, ${ }^{*} p<0.05$ for compared with control group. 


\subsection{Western Blot}

Western blot assay was used to measure the changes in the PARP concentrations of SW1353 cells after PKE or $\mathrm{H}_{2} \mathrm{O}_{2}$ treatment. PARP cleavage was induced by $\mathrm{H}_{2} \mathrm{O}_{2}$, as seen in Figure 7. PKE can prevent the breakage of PARP caused by $\mathrm{H}_{2} \mathrm{O}_{2}$. The fracture in the $\mathrm{H}_{2} \mathrm{O}_{2}$ group is 1.81-fold that of the group with PKE added and $\mathrm{H}_{2} \mathrm{O}_{2}$ co-treatment. These results indicate that PKE-induced apoptosis could block the caspase-dependent apoptosis pathway, which involves the effector caspase-3.
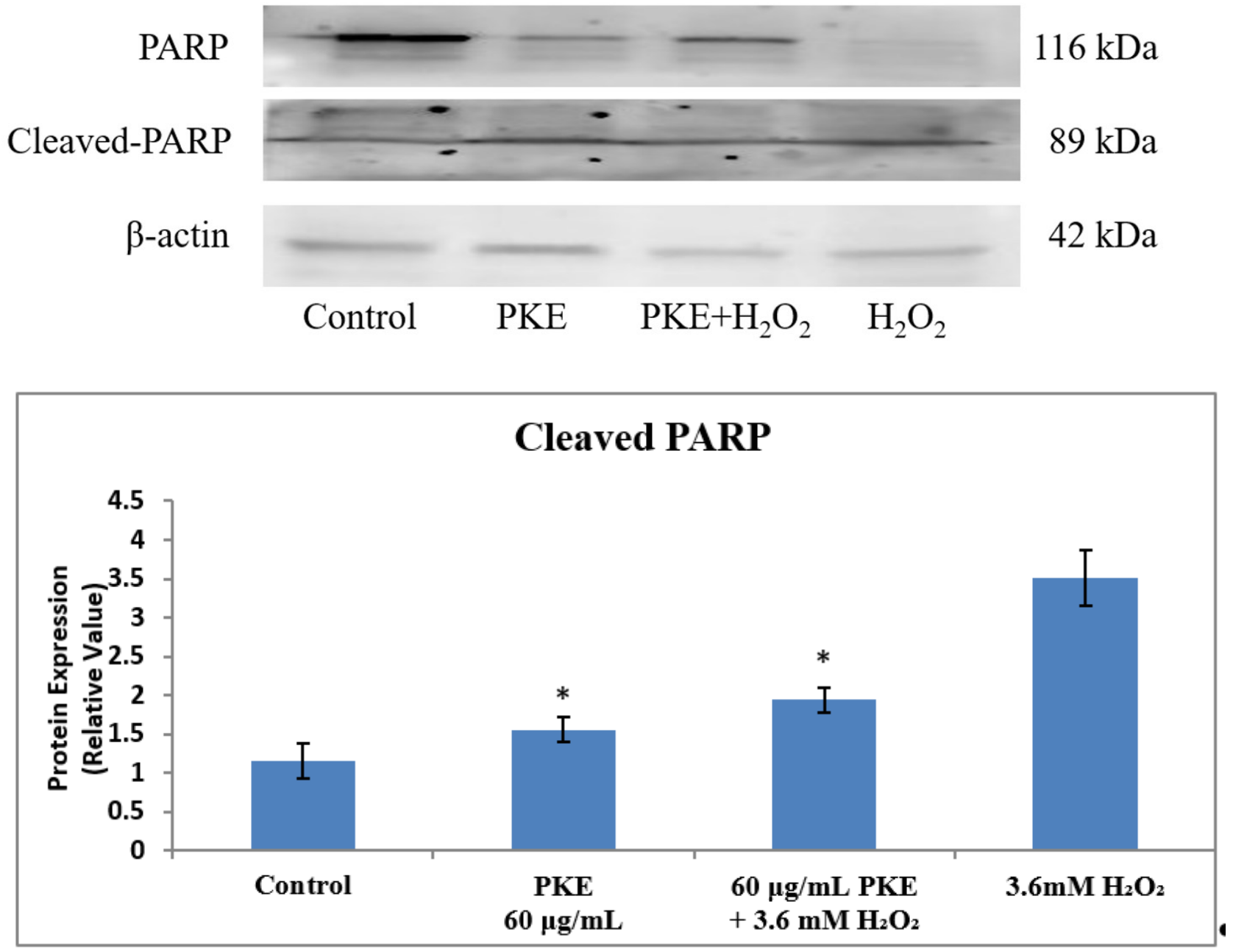

Figure 7. The cleaved PARP in the western blot assay after cells were treated with PKE extract $(60 \mu \mathrm{g} / \mathrm{mL}), \mathrm{PKE}(60 \mu \mathrm{g} / \mathrm{mL})$ with $3.6 \mathrm{mM}$ added $\mathrm{H}_{2} \mathrm{O}_{2}$, and $3.6 \mathrm{mM} \mathrm{H}_{2} \mathrm{O}_{2}$ for $24 \mathrm{~h}$. Values are expressed as mean $\pm \mathrm{SD}(n=3),{ }^{*} p<0.05$ for compared with control group.

\subsection{Composition Identification}

Figure 8a shows that the PKE extract contains multiple peak signals. After manually comparing mass diagrams, we speculate on the structure of the substance and its mass result. Figure $8 \mathrm{~b}$ is the structure of bicyclo [2.2.1] heptan-2-ol, 1,7,7-trimethyl-, (1S-endo)$\left(\mathrm{C}_{10} \mathrm{H}_{18} \mathrm{O}\right)$, Figure $8 \mathrm{c}$ is alpha-humulene $\left(\mathrm{C}_{15} \mathrm{H}_{24}\right)$, Figure $8 \mathrm{~d}$ is hydroxychavicol $\left(\mathrm{C}_{9} \mathrm{H}_{10} \mathrm{O}_{2}\right)$, and Figure $8 \mathrm{e}$ is the dry Piper kadsura. 


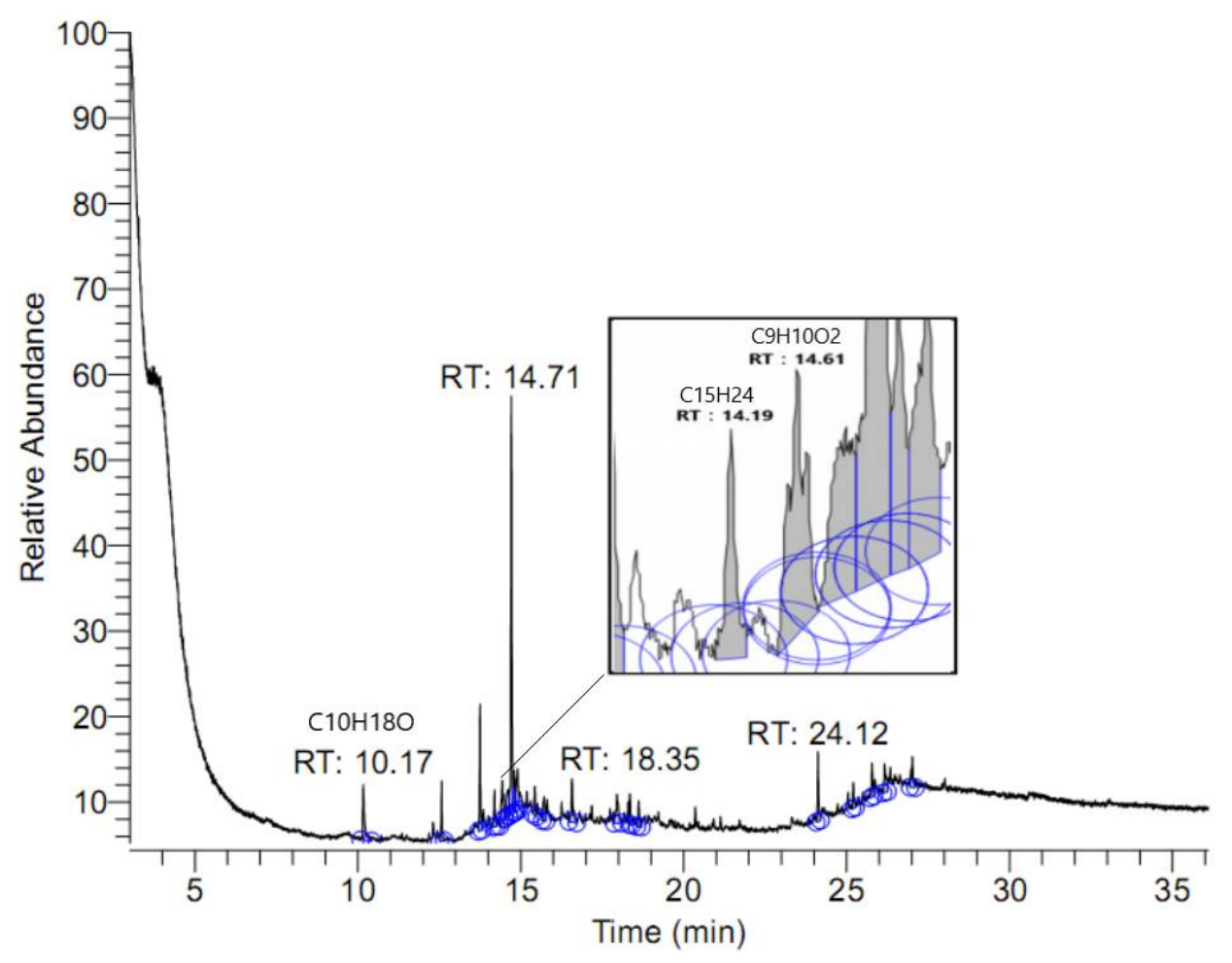

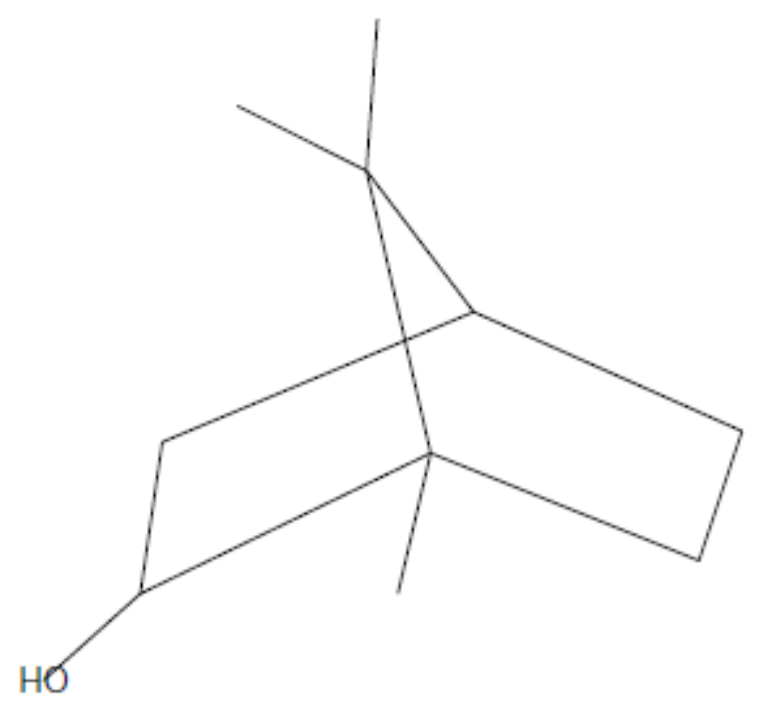

(b)

(a)

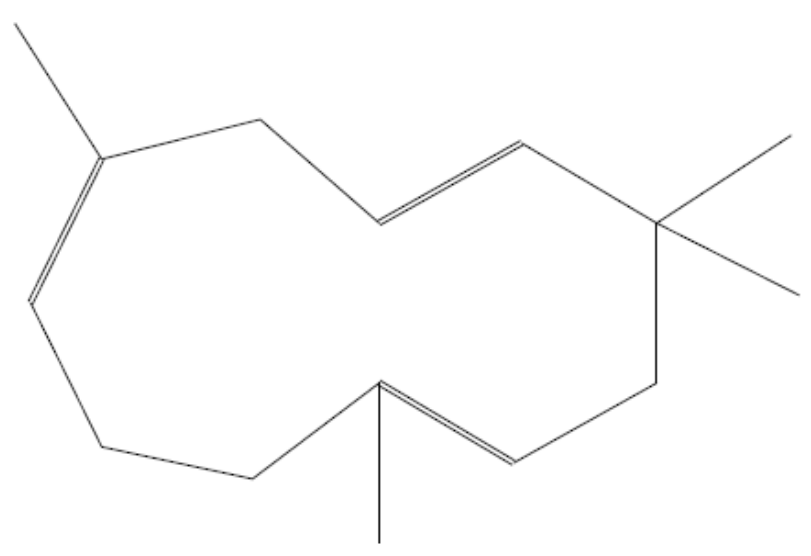

(c)

Figure 8. Cont. 


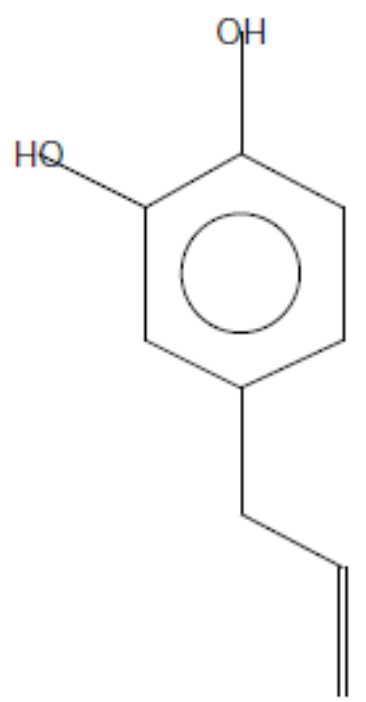

(d)

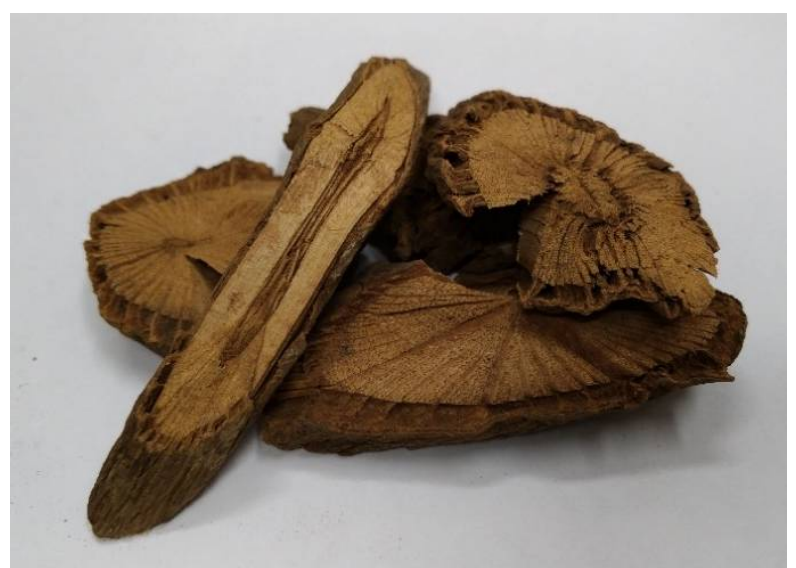

(e)

Figure 8. The peak signals of PKE from GCMS analysis (a), the structure of bicyclo[2.2.1]heptan-2-ol, 1,7,7-trimethyl-, (1S-endo)- (b), alpha-humulene (c), hydroxychavicol (d), and dry Piper kadsura (e).

\section{Materials and Methods}

\subsection{Preparation of the Extracts of P. kadsura}

P. kadsura was purchased from a local grass shop in Taiwan, and then all the samples were crushed into powders of less than $0.30 \mathrm{~mm}$. Different parameters (operating temperature, extraction time, solid/liquid $(\mathrm{g} / \mathrm{mL})$ ratio, and microwave power) were adjusted to optimize the process conditions for maximum yield of extraction. Four-gram powders of $P$. kadsura were mixed with $95 \%$ ethanol and extracted using a microwave-assisted machine (MAS-II Plus, Sineo, Shanghai, China) to determine the best yield of the ethanol extract. The ethanol extract was extracted successively by liquid-liquid extraction with hexane, ethyl ether, and ethyl acetate to obtain a hexane extract, ethyl acetate extract, ethyl acetate extract, and aqueous extract, respectively. On the basis of results of cell viability and antioxidant activity from various liquid-liquid extracts, the ethyl ether extract has the best cell survival rate and antioxidant capacity. Therefore, the ethyl ether extract of $P$. kadsura was subjected to column chromatography with silica gel (230-400 mesh) using hexane-ethyl acetate (6:1), hexane-ethyl acetate (3:1), hexane-ethyl acetate (1:1), and ethyl acetate, and methanol extracting solvent was then used as mobile phase to collect 13 pooled fractions based on their TLC profiles. These various fractions were tested for cell viability and antioxidant activity.

\subsection{Biological Characteristics of P. kadsura Extract}

\subsubsection{Total Polyphenols and Flavonoid Contents Determination}

The total polyphenols of crude and various liquid-liquid extracts of P. kadsura were determined according to the method of Folin-Ciocalteu [18] with some modification. A total of $200 \mu \mathrm{L}$ of extract $(1000 \mathrm{mg} / \mathrm{L})$ or gallic acid $(50-250 \mathrm{mg} / \mathrm{L})$ was mixed with $1.0 \mathrm{~mL}$ of Folin-Ciocalteu reagent $(0.5 \mathrm{M})$ and $1.0 \mathrm{~mL}$ of sodium carbonate solution $(75 \mathrm{~g} / \mathrm{L})$, after $2 \mathrm{~h}$ standing in the dark at room temperature, the optical density was measured at $760 \mathrm{~nm}$ against a blank. The total phenolic contents were calculated on the basis of the calibration curve of gallic acid and expressed as gallic acid equivalents, in mg gallic acid per gram of the dried extract.

The flavonoid contents of crude and various liquid-liquid extracts were measured following the Dowd method [19]. An aliquot of $1 \mathrm{~mL}$ of extract solution $(1000 \mathrm{mg} / \mathrm{L})$ or quercetin (50-250 mg/L) were mixed with $0.1 \mathrm{~mL}$ of $10 \%(w / v) \mathrm{AlCl}_{3}$ solution in methanol, $0.1 \mathrm{~mL}$ potassium acetate $(1.0 \mathrm{M})$, and $5.6 \mathrm{~mL}$ distilled water. The mixture was incubated for 
$45 \mathrm{~min}$ at room temperature, followed by the measurement of absorbance at $415 \mathrm{~nm}$ against the blank. The total flavonoid contents were calculated on the basis of the calibration curve of quercetin and expressed as quercetin equivalents, in mg quercetin per gram of the dried extract.

\subsubsection{Antimicrobial Activity Assay-Disc Diffusion Method}

The five standard strains (A. baumannii ATCC 19606, S. aureus ATCC 6538P, P. aeruginosa ATCC 27853, P. aeruginosa ATCC 29260, E. coli ATCC 25257) were purchased from the Bioresource Collection and Research Center (Hsinchu, Taiwan) and inoculated into $5.0 \mathrm{~mL}$ LB broth and cultivated in a $200 \mathrm{rpm} 37^{\circ} \mathrm{C}$ incubator for 12 to $16 \mathrm{~h}$. A total of $50.0 \mu \mathrm{L}$ strains solution $\left(3 \times 10^{8} \mathrm{CFU} / \mathrm{mL}\right)$ was added to $5.0 \mathrm{~mL}$ LA soft agar, vortexed, and mixed evenly, then poured on the LA medium to form a double layer. We took $30.0 \mu \mathrm{L}$ of crude and various extracts solution $(0.1 \mathrm{~g} / \mathrm{mL})$ into a sterile $6 \mathrm{~mm}$ filter paper disk, with DMSO (dimethyl sulfoxide) as the negative control group and tetracycline $(7.50 \mathrm{mg} / \mathrm{mL})$ as the positive control group. All plates were incubated at $37^{\circ} \mathrm{C}$ for $12-16 \mathrm{~h}$, observed, and measured for the size of the disk inhibition zone (DIZ).

\subsubsection{Antioxidant Activity Analysis-DPPH Free Radical Scavenging Activity}

The 2-2-diphenyl- $\beta$-picrylhydrazyl (DPPH) free radical scavenging test was performed according to the method of Huang et al. [20] with some modifications. Samples (100 $\mu \mathrm{L}$ each) of different concentrations were added to $25 \mu \mathrm{L}$ of $0.5 \mathrm{mM}$ DPPH solution in ethanol, mixed uniformly, and then allowed to stand in the dark for $30 \mathrm{~min}$, followed by spectroscopy at $517 \mathrm{~nm}$. Double-distilled water served as the negative control, and vitamin $\mathrm{C}$ served as the positive control. The radical-scavenging effect was calculated using the following equation:

$$
\text { Scavenging effect }(\%)=\left[1-\left(\mathrm{A}_{\text {sample }}-\mathrm{A}_{\text {blank }}\right) / \mathrm{A}_{\text {control }}\right] \times 100 \%
$$

where $A_{\text {sample }}$ is the sample group absorbance, $A_{\text {blank }}$ is the blank absorbance, and $A_{\text {control }}$ is the absorbance of double-distilled water.

\subsection{Antioxidative Activity In Vitro}

Using SW1353 cells as test subjects, we investigated the protective effects of extracts from P. kadsura on its cytotoxicity and oxidative damage. SW1353 cell was purchased from the Bioresource Collection and Research Center (Hsinchu, Taiwan). These cells were cultured as monolayers in Leibovitz's L15 medium containing 10\% FBS, 1\% penicillin, and streptomycin, and placed in a humidified incubator under $0 \% \mathrm{CO}_{2}$ at $37^{\circ} \mathrm{C}$ for ordinary cultures. The culture medium was changed every 2-3 days.

\subsubsection{Cell Survival Assay and Cell Morphology}

The number of surviving cells after treatment with an extract was measured in terms of the metabolic activity of mitochondrial enzymes, which was based on 3-(4,5-dimethylthiazol2-yl)-2,5-diphenyltetrazolium bromide (MTT). SW1353 cells and L929 fibroblasts were treated with different concentrations of various extracts and hydrogen peroxide for $24 \mathrm{~h}$, and then $5 \mathrm{mg} / \mathrm{mL}$ MTT was added at $37{ }^{\circ} \mathrm{C}$ for $3 \mathrm{~h}$. After the medium was removed, the purple needle-like crystals were dissolved in DMSO, and the absorbance was measured at wavelength of $570 \mathrm{~nm}$ using a spectrophotometer (Multiskan FC, Thermo Fisher Scientific, Waltham, MA, USA). From the results of cell viability from various liquid-liquid extracts and hydrogen peroxide, we chose the PKE as the Fraction 5 of the ethyl ether extract from column chromatography and hydrogen peroxide with co-treatment for further study.

SW1353 cells were cultured initially on six-well tissue culture plates, treated with the PKE $(60 \mu \mathrm{g} / \mathrm{mL})$, PKE $(60 \mu \mathrm{g} / \mathrm{mL})$ with $3.6 \mathrm{mM}$ added $\mathrm{H}_{2} \mathrm{O}_{2}$, and $3.6 \mathrm{mM} \mathrm{H}_{2} \mathrm{O}_{2}$ for $24 \mathrm{~h}$ (based on the optimal results of cell viability). The cells were fixed in situ in $4 \%$ paraformaldehyde for $10 \mathrm{~min}$ to facilitate observation of the cellular morphology. All specimens were examined using a light microscope (CKX53, Olympus). 


\subsubsection{Apoptosis Assay}

SW1353 cells were seeded into six-well tissue culture plates $\left(2 \times 10^{5}\right.$ per well), and then PKE $(60 \mu \mathrm{g} / \mathrm{mL})$, PKE $(60 \mu \mathrm{g} / \mathrm{mL})$ with $3.6 \mathrm{mM}$ added $\mathrm{H}_{2} \mathrm{O}_{2}$, and $3.6 \mathrm{mM} \mathrm{H}_{2} \mathrm{O}_{2}$ were treated for $24 \mathrm{~h}$. The cells were removed from the culture plates and centrifuged at $447.2 \times g$ for $5 \mathrm{~min}$. The supernatant was removed, and the precipitate was suspended in $200 \mu \mathrm{L}$ of $1 \times$ PBS. The suspension was mixed continuously while $800 \mu \mathrm{L}$ of cold ethanol was added, and the cells were stored at $-20^{\circ} \mathrm{C}$ overnight. The extent to which the levels of thiols had decreased indicated overall cell health following extract treatment, according to the manufacturer's protocol for the cell vitality kit (ChemoMetec A/S, Allerod, Denmark). Cell apoptosis assays were detected using a NucleoCounter NC-250 (ChemoMetec A/S, Allerod, Denmark), and these results can explain the cellular apoptosis.

\subsubsection{ROS Assay}

SW1353 cells were seeded into six-well tissue culture plates $\left(2 \times 10^{5}\right.$ per well), and then PKE $(60 \mu \mathrm{g} / \mathrm{mL})$, PKE $(60 \mu \mathrm{g} / \mathrm{mL})$ with $3.6 \mathrm{mM}$ added $\mathrm{H}_{2} \mathrm{O}_{2}$, and $3.6 \mathrm{mM} \mathrm{H}_{2} \mathrm{O}_{2}$ were treated for $24 \mathrm{~h}$. The cells were removed from the culture plates and centrifuged at $113.4 \times g$ for $5 \mathrm{~min}$. The supernatant was removed, and the precipitate was suspended in $200 \mu \mathrm{L}$ of $1 \times$ PBS. The suspension was mixed continuously while $400 \mu \mathrm{M}$ of CM-H2DCFDA was added (control group was replaced by $1 \times$ PBS) to allow reaction for $30 \mathrm{~min}$ in the dark. Post-reaction cells were centrifuged at $188.9 \times g$ for $5 \mathrm{~min}$, and then the precipitate was suspended in $1000 \mu \mathrm{L}$ of PBS for analysis by flow cytometry (BD FACSCalibur ${ }^{\mathrm{TM}}$ Dual Laser, Becton, Dickinson, Franklin Lakes, NJ, USA) at $480 \mathrm{~nm}$ for the excited state and $530 \mathrm{~nm}$ for the emission state.

\subsubsection{Quantitative Real-Time PCR}

SW1353 cells $\left(2 \times 10^{5}\right.$ per well) were seeded into six-well tissue culture plates, and then PKE $(60 \mu \mathrm{g} / \mathrm{mL})$, PKE $(60 \mu \mathrm{g} / \mathrm{mL})$ with $3.6 \mathrm{mM}$ added $\mathrm{H}_{2} \mathrm{O}_{2}$, and $3.6 \mathrm{mM} \mathrm{H}_{2} \mathrm{O}_{2}$ were treated for $24 \mathrm{~h}$. After the medium was removed, the total RNA of cells was extracted using TRIzol reagent $\left(\right.$ Ambion $^{\circledR}$, Life Technologies ${ }^{\mathrm{TM}}, \mathrm{USA}$ ) according to the manufacturer's operating manual. RNA quantity was assessed with Nanodrop One/One ${ }^{\mathrm{C}}$ Spectrophotometer (Thermo Scientific instruments). cDNA was synthesized by reverse transcription using Super Script ${ }^{\circledR}$ III Reverse Transcriptase kit (Life Technologies ${ }^{\mathrm{TM}}$, USA) following protocols from Invitrogen ${ }^{\mathrm{TM}}$ Corporation (USA). Real-time polymerase chain reaction (RT-PCR) was performed using Smart Quant Green Master Mix according to protocols from Protech Technology Enterprise Co., Ltd. (Taiwan). An initial denaturation was performed at $65^{\circ} \mathrm{C}$ for $10 \mathrm{~min}$ followed by 60 cycles of $55^{\circ} \mathrm{C}$ for $30 \mathrm{~min}$ and $85^{\circ} \mathrm{C}$ for $5 \mathrm{~min}$. The relative gene-expression fold change was determined through the $2^{-\triangle \Delta \mathrm{Ct}}$ method and normalized to transcripts of the housekeeper gene GAPDH. The used PCR primers were purchased from Genomics (Taiwan) and listed below: Bcl-2 (Forward: 5'-GAG ACA GCC AGG AGA AAT CA-3', Reverse: $5^{\prime}$-CCT GTG GAT GAC TGA GTA CC-3'); Bax (Forward: 5'-CAT CTT CTT CCA GAT GGT GA-3', Reverse: $5^{\prime}$-GTT TCA TCC AGG ATC GAG CAG-3'); Caspase3 (Forward: 5'-CTC GGT CTG GTA CAG ATG TCG A-3', Reverse: 5'-CAT GGC TCA GAA GCA CAC AAA C-3'); CAT (Forward: 5'-AGA GGA AAC GCC TGT GTG AG-3', Reverse: 5'-TAG TCA GGG TGG ACG TCA GT-3'); SOD-2 (Forward: 5'-GTG TCT GTG GGA GTC CAA G-3', Reverse: 5'-TGC TCC CAC ACA TCA ATC CC-3'); GPx (Forward: 5'-GGA CTA CAC CCA GAT GAA-3', Reverse: 5'-GTG GCG TCG TCA CTT G-3'); GAPDH (Forward: 5'-ATG AGA AGT ATG ACA ACA GCC-3', Reverse: 5'-AGT CCT TCC ACG ATA CCA AA-3').

To investigate the effect of hydrogen peroxide on oxidative stress in SW1353 cells, $100 \mu \mathrm{L}$ of $10 \mu \mathrm{M}$ inhibitors of different MAPKs families (SB 203580, U0126, and SP600125) was added to the medium for $2 \mathrm{~h}$ in culture. Subsequently, these cells were treated with PKE $(60 \mu \mathrm{g} / \mathrm{mL})$, PKE $(60 \mu \mathrm{g} / \mathrm{mL})$ with $3.6 \mathrm{mM}$ added $\mathrm{H}_{2} \mathrm{O}_{2}$, and $3.6 \mathrm{mM} \mathrm{H}_{2} \mathrm{O}_{2}$ for $24 \mathrm{~h}$, and then the gene expression of Bax, Bcl-2, and SOD-2 was analyzed by qRT-PCR. 


\subsubsection{Western Blotting}

SW1353 cells $\left(1.2 \times 10^{6}\right.$ per dish) were cultured overnight, and then added PKE $(60 \mu \mathrm{g} / \mathrm{mL})$, PKE $(60 \mu \mathrm{g} / \mathrm{mL})$ with $3.6 \mathrm{mM}$ added $\mathrm{H}_{2} \mathrm{O}_{2}$, and $3.6 \mathrm{mM} \mathrm{H}_{2} \mathrm{O}_{2}$ were treated for $24 \mathrm{~h}$. After the medium was removed, the total cell protein was extracted by lysing the cells in a buffer containing $50 \mathrm{mM}$ Tris- $\mathrm{Cl}, 150 \mathrm{mM} \mathrm{NaCl}, 0.1 \%$ Triton X-100, $0.1 \%(\mathrm{~m} / \mathrm{v})$ $\mathrm{SDS}, 1.0 \mathrm{mM}$ sodium orthovanadate, and $1 \mathrm{mM} \mathrm{NaF}$ at $\mathrm{pH}$ 8.0. Protein concentrations were determined by Bradford protein assay at an absorbance of $595 \mathrm{~nm}$. Equal amounts of proteins were subjected to $10 \%$ SDS-polyacrylamide gel (SDS-PAGE), electrically transferred onto polyvinylidene fluoride (PVDF) membranes (Millipore, Billerica, MA, USA), blocked with blocking buffer ( $5 \%$ skimmed milk powder in PBS), and then probed with primary antibodies (PARP; 1:1000; Cell Signaling Technology, Danvers, MA, USA) overnight at $4{ }^{\circ} \mathrm{C}$. Blots were washed and incubated for $1 \mathrm{~h}$ with IRDye $800^{\circledR}$-conjugated secondary antibodies (1:8000; Cell Signaling Technology, USA), and then washed with $0.1 \%$ Tween-20 in Tris-buffered saline (TBS). The proteins were visualized via chemiluminescence using the Amersham ECL Plus Western Blotting Detection kit (GE Healthcare, Chicago, IL, USA) according to the manufacturer's instructions. $\beta$-Actin (Cell Signaling Technology, USA) was used as the loading control for protein expression in the treated cells.

\subsection{Composition Identification}

The exact components of PKE were identified by gas chromatography-mass spectrometry (JEOL, AccuTOF GCX). PKE (1.25 mg dissolved in $0.5 \mathrm{~mL}$ methanol) was taken, and then $0.5 \mu \mathrm{L}$ was injected into the column (Rxi-5MS, $30 \mathrm{~m}$, I.D. $0.25 \mathrm{~mm}, 0.25 \mu \mathrm{m}$ film). Initial temperature was $40{ }^{\circ} \mathrm{C}$; it was heated to $300{ }^{\circ} \mathrm{C}$ at a rate of $10^{\circ} \mathrm{C}$ per minute and retained for $10 \mathrm{~min}$. The carrier gas of the column was helium, and the flow rate was $1 \mathrm{~mL} / \mathrm{min}$.

\subsection{Statistical Analysis}

All experiments with multiple samples were performed thrice. Data were presented as mean \pm standard deviation (SD), and ANOVA was used to treat data. Statistical comparisons were performed, and comparisons with $\mathrm{p}$ values smaller than 0.05 were considered significant.

\section{Discussion}

Ethanol and water are often used for traditional Chinese herbal medicine extraction. However, the preservation of water extracts is more difficult than that of ethanol extracts. Water also easily extracts more sugars, starches, and other substances, which makes the boiling point of the extract increase or gelatinize the extract, resulting in difficulties in subsequent concentration and drying. Ethanol has a higher selectivity than water and can effectively obtain plant secondary metabolites [21]; hence, 95\% ethanol was used as extraction solvent in this study.

The extracted substance decreases with the increase of the extraction time after $30 \mathrm{~min}$ by MAE. The reason for this may be the degradation of volatile oils in plants [22]. In addition, the extraction yields begin to decrease when the temperature is higher than $42{ }^{\circ} \mathrm{C}$ and the power exceeds $800 \mathrm{~W}$. It may be because the viscosity and surface tension of the solvent can be reduced at high temperatures to promote accelerated extraction, but it could also be the degradation of volatile oils in plants [23,24]. Natural plant compounds are highly compatible with organic solvents because of their structure and polarity, so their bonding ability is also different with various solvents [21]. Therefore, different types of compounds can be assigned to different solvents to achieve the effect of separation by washing with different eluents from low- to high-polarity solvent. In this study, from the lowest polarity (n-hexane) to the most highly polar solvent (ethyl acetate), the different substances were separated into the solvents, and the substances that could not be distributed to the organic solvent were left in the aqueous phase. Most of the polyphenols (including flavonoids) exist in the ethyl ether extraction, which also has the greatest antimicrobial ability. It was 
found that most active substances were first dissolved in the ethyl ether solvent and then mixed with different polar solvents for column chromatography and TLC to separate them into 13 fractions. These fractions were tested for cell viability and antioxidant activity, and the most effective components in Fraction 5 were confirmed to be PKE.

Oxidative damage can lead to degenerative diseases and chronic non-infectious diseases. However, antioxidants from natural plants have showed significant cellular protection properties. Pepper plants can be found in tropical and subtropical regions of the world. About 2000 different types of pepper plants have been counted, and piper is the largest species. Most of them have natural antioxidant activity [25-28]. Here, we observed that the crude extract of P. kadsura has good antioxidant activity, as indicated by the DPPH test, and that the antioxidant capacity of the extract can be promoted through the purification process. As a result, it was found that the antioxidant activity of various fractions separated from the ethyl ether extract after column chromatography purification were more than $50 \%$, with $\mathrm{EC}_{50}$ values less than $20 \mu \mathrm{g} / \mathrm{mL}$; three of them were below $10 \mu \mathrm{g} / \mathrm{mL}$. Through the increase of ROS, $\mathrm{H}_{2} \mathrm{O}_{2}$ can be used for cellular ROS induction that provides free radicals to simulate the situation when the load capacity of cells is exceeded in the organism [29]. The increase of ROS in chondrocytes is considered to be related to the dysfunction of cells and the degradation of articular cartilage, which may lead to cartilage aging or arthritis. When cells encounter harmful conditions caused by ROS, the cells induce antioxidant enzymes such as SOD, CAT, and GPx as a compensation mechanism to ensure the integrity of the cells [30]. SW1353 cells treated with $\mathrm{H}_{2} \mathrm{O}_{2}$ alone could regulate antioxidant enzyme SOD-2, CAT, and GPx to promote cell apoptosis and stimulate downstream-of-MAPKfamily protein kinases. This then regulates Bax and Bcl-2 on the mitochondrial membrane and then activates caspase-3, and cuts off PARP, leading to cell death. Activated MAPKs participate in various signal stimulations in induced chondrocyte apoptosis, which mediate cell survival and proliferation; the results after regulation are related to cartilage degenerative diseases. The combined treatment of PKE and $\mathrm{H}_{2} \mathrm{O}_{2}$ can reverse the effect of $\mathrm{H}_{2} \mathrm{O}_{2}$ alone and effectively slow down the consumption of antioxidant enzymes CAT, GPx, and SOD-2 by $\mathrm{H}_{2} \mathrm{O}_{2}$, thus increasing Bcl-2/Bax expression and regulating the performance of caspase- 3 and PARP. Through the addition of inhibitors, it is found that all of the MAPKs are the key to regulation. The three pathways of JNK [1], MEK/ERK [31], and p38 [32] are regulated by regulating GPx, CAT, and SOD-2 in cells to protect the regulation of Bcl-2 and Bax on the mitochondrial membrane. PKE was found to promote cell proliferation in the MTT test, and it was confirmed in the results of the cell morphology observation and cell apoptosis analysis. The performance of SOD-2, CAT, and GPx genes was enhanced in the qRT-PCR assay. $\mathrm{H}_{2} \mathrm{O}_{2}$ itself is related to various inflammatory diseases of the body, which have the ability to induce cell inflammation $[6,33,34]$. In this study, the relationship between cells and MAPK was used to clarify the possible pathways of PKE, as shown in Figure 9. It has not been thoroughly explored whether PKE has full anti-inflammatory ability. It is only confirmed through the gene end of the cell that MAPKs and antioxidant enzymes CAT are indeed regulated by $\mathrm{H}_{2} \mathrm{O}_{2}$, and that PKE can indeed alleviate the damage caused by $\mathrm{H}_{2} \mathrm{O}_{2}$ and protect the cells against inflammation response.

The main anti-inflammatory composition of the PKE was analyzed by GC-MS, and it was determined that there were bicyclo [2.2.1] heptan-2-ol-1,7,7-trimethyl-, (1S-endo)-, $\mathrm{C}_{10} \mathrm{H}_{18} \mathrm{O}$, alpha-humulene, $\mathrm{C}_{15} \mathrm{H}_{24}$ and hydroxychavicol, and $\mathrm{C}_{9} \mathrm{H}_{10} \mathrm{O}_{2}$. Bicyclo [2.2.1] heptan-2-ol-1,7,7-trimethyl-, (1S-endo)- is a stereoisomer of borneol, which has been proven to have cytoprotective effects in the literature $[35,36]$. However, if the concentration is greater than $2 \mathrm{mM}$, it may cause damage to cells. Alpha-humulene is a sesquiterpene found in many plants that has been shown to protect nerve cells [37] and have anti-inflammatory effects [38]. Hydroxychavicol is a polyphenol and has good antioxidant capacity [39]. It is also a xanthine oxidase inhibitor and can be used clinically to treat hyperuricemia [40]. 


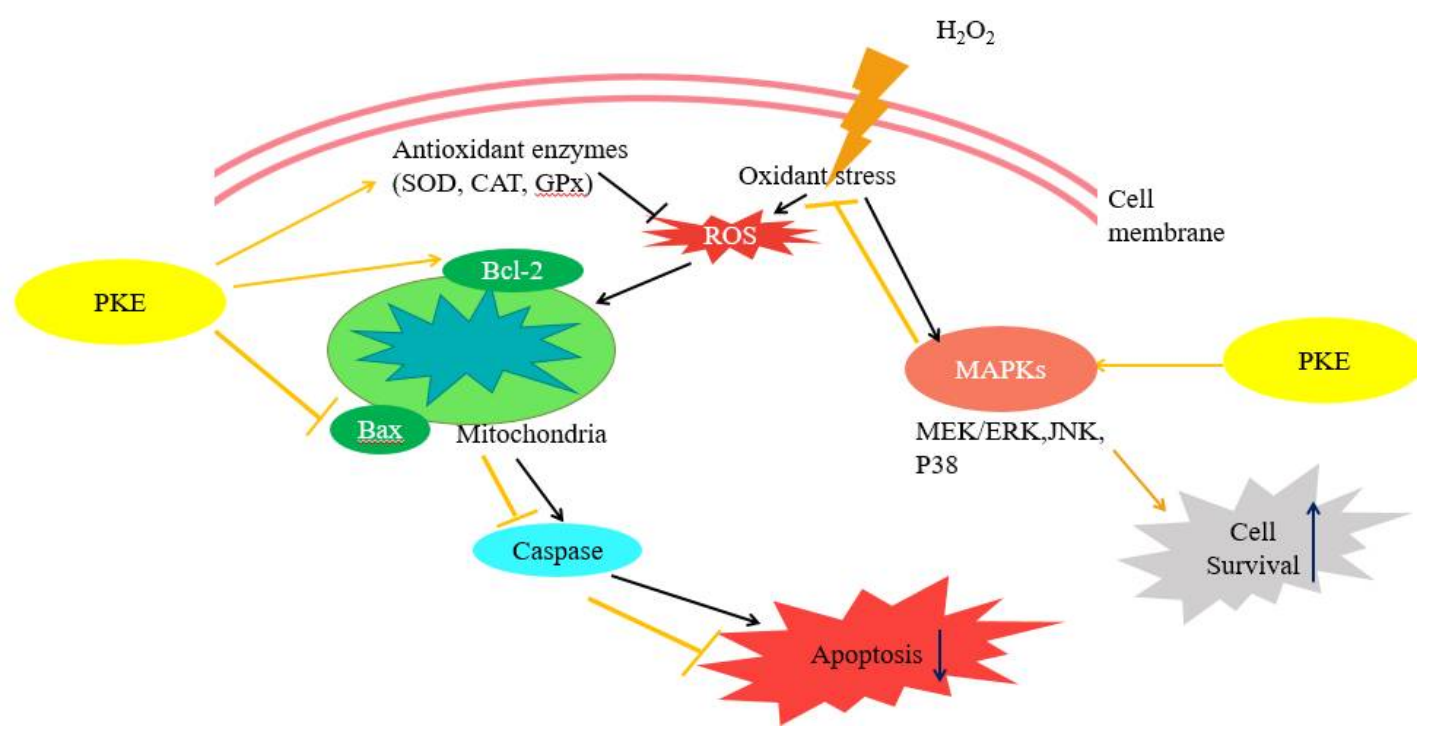

Figure 9. The possible routes by which PKE protects SW1353 from oxidative stress through JNK, MEK/ERK, and p38 pathways.

\section{Conclusions}

Biologically active substances contained in $P$. kadsura were obtained by extraction and column chromatography. The optimum conditions for MAE were $42{ }^{\circ} \mathrm{C}, 800 \mathrm{~W}, 30 \mathrm{~min}, 1 \mathrm{~g}$ piper, and $15 \mathrm{~mL}$ of $95 \%$ ethanol. PKE had good DPPH removal efficiency, and it could effectively protect cells from $\mathrm{H}_{2} \mathrm{O}_{2}$ attack and prevent cell death. The substances of PKE that can protect the cells may be bicyclo [2.2.1] heptan-2-ol-1,7,7-trimethyl-(1S-endo)-, alphahumulene, and hydroxychavicol, which were shown to be present via GC-MS identification. SW1353 chondrosarcoma cells were significantly protected from $\mathrm{H}_{2} \mathrm{O}_{2}$ assault by PKE, likely via regulation of MAPKs signals and modulation of mitochondrial pathways.

Author Contributions: This work was carried out in collaboration among all authors. T.-Y.H. and W.-T.S. designed the study and analyzed the data. C.-C.W. performed the experiments. T.-Y.H. and W.-T.S. provided material support and technical assistance. T.-Y.H. and W.-T.S. obtained the funding. W.-T.S. wrote and reviewed the manuscript. All authors have read and agreed to the published version of the manuscript.

Funding: The authors would like to acknowledge the financial support received from NTUT-MMH Joint Research Program (NTUT-MMH-No. 110-02) and Ministry of Science and Technology (contract no. MOST 108-2221-E-027-076).

Institutional Review Board Statement: Not applicable.

Informed Consent Statement: Not applicable.

Data Availability Statement: Not applicable.

Conflicts of Interest: The authors declare no conflict of interest.

Sample Availability: Samples of the compounds are not available.

\section{References}

1. Na, J.Y.; Song, K.; Kim, S.; Kwon, J. Rutin protects rat articular chondrocytes against oxidative stress induced by hydrogen peroxide through SIRT1 activation. Biochem. Biophys. Res. Commun. 2016, 473, 1301-1308. [CrossRef]

2. Cheleschi, S.; Da Palma, A.; Pascarelli, N.A.; Giordano, N.; Galeazzi, M.; Tenti, S.; Fioravanti, A. Could oxidative stress regulate the expression of microRNA-146a and microRNA-34a in human osteoarthritic chondrocyte cultures? Int. J. Mol. Sci. 2017, 18, 2660. [CrossRef]

3. Hu, Z.C.; Grong, L.F.; Li, X.B.; Fu, X.; Xuan, J.W.; Feng, Z.H.; Ni, W.F. Inhibition of PI3K/Akt/NF-kB signaling with leonurine for ameliorating the progression of osteoarthritis: In vitro and in vivo studies. J. Cell. Physiol. 2018, 234, 6940-6950. [CrossRef] 
4. Bolduc, J.A.; Collins, J.A.; Loeser, R.F. Reactive oxygen species, aging and articular cartilage homeostasis. Free Radic. Biol. Med. 2019, 132, 73-82. [CrossRef]

5. Pizzino, G.; Irrera, N.; Cucinotta, M.; Pallio, G.; Mannino, F.; Arcoraci, V.; Squardrito, F.; Altavilla, D.; Bitto, A. Oxidative Stress: Harms and Benefits for Human Health. Oxid. Med. Cell. Longev. 2017, 2017, 8416763. [CrossRef] [PubMed]

6. Young, I.C.; Chuang, S.T.; Hsu, C.H.; Sun, Y.J.; Lin, F.H. C-phycocyanin alleviates osteoarthritic injury in chondrocytes stimulated with $\mathrm{H}_{2} \mathrm{O}_{2}$ and compressive stress. Int. J. Biol. Macromol. 2016, 93, 852-859. [CrossRef] [PubMed]

7. Son, Y.; Cheong, Y.K.; Kim, N.H.; Chung, H.T.; Kang, D.G.; Pae, H.O. Mitogen-Activated Protein Kinases and Reactive Oxygen Species: How Can ROS Activate MAPK Pathways? J. Signal Transduct. 2011, 2011, 792639. [CrossRef]

8. Lepetsos, P.; Papavassiliou, K.V.; Papavassiliou, A.G. Redox and NF-кB signaling in osteoarthritis. Free Radic. Biol. Med. 2019, 132, 90-100. [CrossRef] [PubMed]

9. Gebauer, M.; Saas, J.; Sohler, F.; Haag, J.; So, S.; Pieper, M.; Bartnik, E.; Beninga, J.; Zimmer, R.; Aigner, T. Comparison of the chondrosarcoma cell line SW1353 with primaryhuman adult articular chondrocytes with regard to their gene expression profile and reactivity to IL-1b. Osteoarthr. Cartil. 2005, 13, 697-708. [CrossRef]

10. Park, C.; Hong, S.H.; Shin, S.S.; Lee, D.S.; Han, M.H.; Cha, H.J.; Kim, S.; Kim, H.S.; Kim, G.Y.; Park, E.K.; et al. Activation of the Nrf2/HO-1 signaling pathway contributes to the protective effects of sargassum serratifolium extract against oxidative stress-induced DNA damage and apoptosis in SW1353 human chondrocytes. Int. J. Environ. Res. Public Health 2018, $15,1173$. [CrossRef]

11. Liu, C.C.; Zhang, Y.; Dai, B.L.; Ma, Y.J.; Zhang, Q.; Wang, Y.; Yang, H. Chlorogenic acid prevents inflammatory responses in IL-1 $\beta$-stimulated human SW-1353 chondrocytes, a model for osteoarthritis. Mol. Med. Rep. 2017, 16, 1369-1375. [CrossRef] [PubMed]

12. Lin, L.C.; Shen, C.C.; Shen, Y.C.; Tsai, T.H. Anti-inflammatory Neolignans from Piper kadsura. J. Nat. Prod. 2006, 69, 842-844. [CrossRef] [PubMed]

13. Kim, J.K.H.; Choi, W.; Ha, S.K.; Kim, S.Y.; Lee, K.R. Neolignans from Piper kadsura and their anti-neuroinflammatory activity. Bioorg. Med. Chem. Lett. 2010, 20, 409-412. [CrossRef] [PubMed]

14. Li, R.W.; Lin, G.D.; Myers, S.P.; Leach, D.N. Anti-inflammatory activity of Chinese medicinal vine plants. J. Ethnopharmacol. 2003, 85, 61-67. [CrossRef]

15. Chiou, W.F.; Peng, C.H.; Chen, C.F.; Chou, C.J. Anti-inflammatory properties of piperlactam s: Modulation of complement 5a-induced chemotaxis and inflammatory cytokines production in macrophages. Planta Med. 2003, 69, 9-14. [CrossRef]

16. Tsai, J.Y.; Chou, C.J.; Chen, C.F.; Chiou, W.F. Antioxidant activity of piperlactam S: Prevention of copper-induced ldl peroxidation and amelioration of free radical-induced oxidative stress of endothelial cells. Planta Med. 2003, 69, 3-8. [CrossRef]

17. Malviya, R.; Sharma, P.K.; Dubey, S.K. Modification of polysaccharides: Pharmaceutical and tissue engineering applications with commercial utility (patents). Mater. Sci. Eng. C-Mater. Biol. Appl. 2016, 68, 929-938. [CrossRef]

18. Aryal, S.; Baniya, M.K.; Danekhu, K.; Kunwar, P.; Gurung, R.; Koirala, N. Total phenolic content, flavonoid content and antioxidant potential of wild vegetables from western nepal. Plants 2019, 8, 96. [CrossRef]

19. Arvouet-Grand, A.; Vennat, B.; Pourrat, A.; Legret, P. Standardization of propolis extract and identification of principal constituents. J. Pharm. Belg. 1994, 49, 462.

20. Huang, T.Y.; Huang, M.Y.; Tsai, C.K.; Su, W.T. Enhanced the biological activity of levan phosphorylated by microwave-assisted synthesis. J. Biosci. Bioeng. 2021, 131, 98-106. [CrossRef]

21. Milena, V.; Tatjana, M.; Gökhan, Z.; Ivana, B.; Aleksandra, C.; Mohammad, M.F.; Marija, R. Advantages of contemporary extraction techniques for the extraction of bioactive constituents from black elderberry (Sambucus nigra L.) flowers. Ind. Crop. Prod. 2019, 136, 93-101. [CrossRef]

22. Mollaei, S.; Sedighi, F.; Habibi, B.; Hazrati, S.; Asgharian, P. Extraction of essential oils of Ferulago angulata with microwave-assisted hydrodistillation. Ind. Crop. Prod. 2019, 137, 43-51. [CrossRef]

23. Cassol, L.; Rodrigues, E.; Noreña, C.P.Z. Extracting phenolic compounds from Hibiscus sabdariffa L. calyx using microwave assisted extraction. Ind. Crop. Prod. 2019, 133, 168-177. [CrossRef]

24. Şen, F.B.; Aşçı, Y.S.; Bekdeşer, B.; Bener, M.; Apak, R. Optimization of Microwave-Assisted Extraction (MAE) for the Isolation of Antioxidants from Basil (Ocimum basilicum L.) by Response Surface Methodology (RSM). Anal. Lett. 2019, 52, 2751-2763. [CrossRef]

25. de Oliveira, M.S.; de Cruz, J.N.; Gomes Silva, S.; da Costa, W.A.; de Sousa, S.H.B.; Bezerra, F.W.F.; Teixeira, E.; da Silva, N.J.N.; de Aguiar Andrade, E.H.; de Jesus Chaves Neto, A.M.; et al. Phytochemical profile, antioxidant activity, inhibition of acetylcholinesterase and interaction mechanism of the major components of the Piper divaricatum essential oil obtained by supercritical $\mathrm{CO}_{2}$. J. Supercrit. Fluids 2019, 145, 74-84. [CrossRef]

26. Ismail, S.M.; Chua, K.H.; Aminunddin, A.; Ugusman, A. Piper sarmentosum as an antioxidant: A Systematic Review. Sains Malays. 2018, 47, 2359-2368. [CrossRef]

27. Ali, A.X.; Lim, Y.; Chong, C.H.; Mah, S.H.; Chua, B.L. Ultrasound-assisted extraction of natural antioxidants from betel leaves (Piper betle): Extraction kinetics and modeling. Sep. Sci. Technol. 2018, 53, 2192-2205. [CrossRef]

28. Takahashi, M.; Hirose, N.; Ohno, S.; Arakaki, M.; Wada, K. Flavor characteristics and antioxidant capacities of hihatsumodoki (Piper retrofractum Vahl) fresh fruit at three edible maturity stages. J. Food Sci. Technol. 2018, 55, 1295-1305. [CrossRef] [PubMed] 
29. Zhuang, C.; Wang, Y.; Zhang, Y.; Xu, N. Oxidative stress in osteoarthritis and antioxidant effect of polysaccharide from Angelica sinensis. Int. J. Biol. Macromol. 2018, 115, 281-286. [CrossRef] [PubMed]

30. Bettaib, J.; Talarmin, H.; Droguet, M.; Magné, C.; Boulaab, M.; Giroux-metges, M.A.; Ksouri, R. Tamarix gallica phenolics protect IEC-6 cells against $\mathrm{H}_{2} \mathrm{O}_{2}$ induced stress by restricting oxidative injuries and MAPKs signaling pathways. Biomed. Pharmacother. 2017, 89, 490-498. [CrossRef]

31. Li, D.; Liu, Y.; Xu, R.; Jia, X.; Li, X.; Huo, C.; Wang, X. Astragalus polysaccharide alleviates $\mathrm{H}_{2} \mathrm{O}_{2}$-triggered oxidative injury in human umbilical vein endothelial cells via promoting KLF2. Artif. Cells Nanomed. Biotechnol. 2019, 47, 2188-2195. [CrossRef] [PubMed]

32. Wu, Y.; Wang, F.; Fan, L.; Zhang, W.; Wang, T.; Du, Y.; Bai, X. Baicalin alleviates atherosclerosis by relieving oxidative stress and inflammatory responses via inactivating the NF- $\mathrm{kB}$ and p38 MAPK signaling pathways. Biomed. Pharmacother. 2018, 97, 1673-1679. [CrossRef] [PubMed]

33. Zhuang, C.; Xu, N.W.; Gao, G.M.; Ni, S.; Miao, K.S.; Li, C.K.; Wang, L.M.; Xie, H.G. Polysaccharide from Angelica sinensis protects chondrocytes from $\mathrm{H}_{2} \mathrm{O}_{2}$-induced apoptosis through its antioxidant effects in vitro. Int. J. Biol. Macromol. 2016, 87, 322-328. [CrossRef]

34. Guo, Y.X.; Liu, L.; Yan, D.Z.; Guo, J.P. Plumbagin prevents osteoarthritis in human chondrocytes through Nrf-2 activation. Mol. Med. Rep. 2017, 15, 2333-2338. [CrossRef]

35. Horváthová, E.; Slameňová, D.; Maršálková, L.; Šramková, M.; Wsólová, L. Effects of borneol on the level of DNA damage induced in primary rat hepatocytes and testicular cells by hydrogen peroxide. Food Chem. Toxicol. 2009, 47, 1318-1323. [CrossRef]

36. Slameňová, D.; Horváthováa, E.; Wsólovác, L.; Šramkova, M.; Navarová, J. Investigation of anti-oxidative, cytotoxic, DNAdamaging and DNA-protective effects of plant volatiles eugenol and borneol in human-derived HepG2, Caco-2 and VH10 cell lines. Mutat. Res. 2009, 677, 46-52. [CrossRef] [PubMed]

37. Elmann, A.; Mordechay, S.; Rindner, M.; Larkov, O.; Elkabetz, M.; Ravid, U. Protective effects of the essential oil of salvia fruticosa and its constituents on astrocytic susceptibility to hydrogen peroxide-induced cell death. J. Agric. Food Chem. 2009, 57, 6636-6641. [CrossRef]

38. Fernandes, E.S.; Passos, G.F.; Medeiros, R.; da Cunha, F.M.; Ferreira, J.; Campos, M.M.; Pianowski, L.F.; Calixto, J.B. Antiinflammatory effects of compounds alpha-humulene and (-)-trans-caryophyllene isolated from the essential oil of Cordia verbenacea. Eur. J. Pharmacol. 2007, 569, 228-236. [CrossRef] [PubMed]

39. Atiya, A.; Sinha, B.N.; Lal, U.R. The new ether derivative of phenylpropanoid and bioactivity was investigated from the leaves of Piper betle L. Nat. Prod. Res. 2020, 34, 638-645. [CrossRef]

40. Murata, K.; Nakao, K.; Hirata, N.; Namba, K.; Nomi, T.; Kitamura, Y.; Moriyama, K.; Shintani, T.; Iinuma, M.; Matsuda, H. Hydroxychavicol: A potent xanthine oxidase inhibitor obtained from the leaves of betel, Piper betle. J. Nat. Med. 2009, 63, 355-359. [CrossRef] [PubMed] 